\title{
Pro-Cyclical Capital Regulation and Lending
}

\author{
Markus Behn, Rainer Haselmann`, and Paul Wachtel ${ }^{\ddagger}$
}

July 30, 2013

\begin{abstract}
We combine particular institutional features of the stepwise introduction of asset risk-specific capital charges by German banks with the event of the Lehman shock to test the theory of pro-cyclicality of capital regulation and to quantify the magnitude of this regulation on firms' access to lending. The Lehman shock resulted in an increase of credit risk during the implementation period of the internal ratings-based (IRB) approach to capital regulation. At this point, banks introducing IRB had transferred only a portion of their loan portfolios to the new approach. Exploiting the variation of the regulatory approach within IRB banks and the fact that many firms borrow from several IRB banks at the same time allows us to systematically control for both bank-level and firm-level heterogeneity. Loans to the same firm decline by about 3.5 percent more when the loan is part of an IRB portfolio as compared with a portfolio using the traditional regulatory approach. Since banks tend to reduce especially large IRB credit exposures during the recession, firms relying on IRB loans experience an even stronger reduction in aggregate borrowing (5 to 10 percent larger) as compared with firms relying on loans under the traditional approach. Our findings have important implications for the design of capital regulation (i.e., Basel III).
\end{abstract}

Keywords: capital regulation, credit crunch, financial crisis, pro-cyclicality

JEL Classification: G01, G21, G28

\footnotetext{
${ }^{*}$ Bonn Graduate School of Economics, Bonn University

${ }^{\dagger}$ Bonn University

†Stern School of Business, New York University.
}

Note: We would like to thank Puriya Abbassi, Iftekhar Hasan, Robert Hauswald, Martin Hellwig, and Vikrant Vig for their helpful comments. We are grateful to the Deutsche Bundesbank, especially to Klaus Düllmann and Thomas Kick, for their generous support with the construction of the data set and deep insights regarding the German banking sector. Peik Achtert, Stefan Duckheim, Birgit Maletzke, Christoph Memmel, and Wolfram Öhlertz provided us with valuable insights regarding the institutional details surrounding the introduction of asset-specific risk weights by German banks. The usual disclaimer on errors applies here as well. 


\section{Introduction}

The design of banks' capital charges has long been one of the most important and controversial issues in discussions of bank regulation. ${ }^{1}$ Prior to the financial crisis, much of the effort to improve regulation was concentrated on the microprudential goal of a better alignment of capital charges with banks' actual asset risk. Although this idea was already present in the Basel I agreement of 1988, Basel II went a step further by introducing the concept of internal ratings-based (IRB) capital requirements. Under the IRB approach, the amount of capital a bank has to hold for a given loan is a function of the model-based, estimated risk of that loan. Many of the world's larger banks are now using their own rating models to determine capital charges for individual credit risks. ${ }^{2}$

There is an argument that linking capital charges to asset risk may exacerbate business cycle fluctuations (see Daníelsson et al. 2001, Kashyap and Stein 2004, Repullo and Suarez 2012). Specifically, capital requirements will increase in a downturn if measures of asset risk are responsive to economic conditions, while at the same time bank capital is likely to be eroded by losses. Capital constrained banks that are unable or unwilling to raise new equity in bad times will be forced to deleverage by cutting back lending activities, hence exacerbating the initial downturn. ${ }^{3}$ In this paper, we causally identify the effect of asset-specific, risk-based capital charges on banks' lending behavior and firms' aggregate borrowing around the financial crisis in Germany. Hence, we estimate the magnitude of the pro-cyclical effects of model-based capital regulation on lending during a downturn.

While the pro-cyclicality of Basel II has been widely discussed in the academic as well as in the policy literature, ${ }^{4}$ three issues beset empirical identification of the effects on

\footnotetext{
${ }^{1}$ See Peltzman (1970), Koehn and Santomero (1980), Kim and Santomero (1988), Blum and Hellwig (1995), Diamond and Rajan (2000, 2001), Morrison and White (2005), or Acharya (2009). An early review of the literature is provided by Bhattacharya et al. (1998).

${ }^{2}$ Over 100 countries have implemented the agreement, with more than half using the more advanced methodology for individual credit risks (see Financial Stability Institute 2010).

${ }^{3}$ Admati et al. (2012) show that even if raising capital is possible, bank shareholders are likely to prefer reducing assets over raising new capital in order to fulfill regulatory requirements.

${ }^{4}$ See Borio et al. (2001), Lowe (2002), Goodhart et al. (2004), Gordy and Howells (2006), Rochet (2008), or Repullo et al. (2010). Brunnermeier (2009) and Hellwig (2009) discuss how pro-cyclical features of the regulation contributed to the financial crisis.
} 
lending. First, the assessment of asset-specific risk and the lending decision of a bank are endogenous. If a bank increases lending to a firm, the firm's leverage increases, and this will increase the mode-based estimation of credit risk. Thus, the relationship between bank lending decisions and firm credit risk may suffer from reverse causality. Second, economic downturns are likely to affect both a firm's loan demand and the evaluation of its credit risk by banks. Therefore, it is essential to disentangle a shock to a firm's loan demand from a potential loan supply shock. Third, economic downturns are likely to have a differential impact on banks. Thus, it is difficult to determine whether a change in bank lending is driven by the pro-cyclicality of capital regulation or the way the bank is affected by the recession shock. The latter concern is an important identification challenge, since larger German banks introduced the IRB approach while most smaller banks continue to use the traditional approach to determine capital charges. ${ }^{5}$ If large banks are affected differently by an economic downturn, as compared with small banks, it is difficult to disentangle the effect of capital regulation on lending from other bank-specific factors.

We overcome all these identification issues by exploiting the institutional arrangements surrounding the introduction of the Basel II Accords in Germany in 2007 (see Bundesbank 2006 for details). Following this reform, banks were allowed to use their own internal risk models to determine the regulatory capital for their loan portfolios. To do so, banks had to apply to German banking authorities for certification of their risk models; such banks are referred to as IRB institutions. Alternatively, banks may also remain under the old regime, which assigns a fixed capital charge to all loans irrespective of their risk; such banks are referred to as standard-approach (SA) institutions. ${ }^{6}$ For those banks that decided to become IRB institutions, the regulator separately certified the internal model for each loan portfolio within the bank, before the IRB approach could be used to determine capital charges. Since this certification process took several years, IRB institutions were using the new (IRB) approach to determine capital charges for some loan portfolios and the traditional

\footnotetext{
${ }^{5}$ In the traditional or standard approach capital requirements do not depend on asset risk or economic conditions and are constant over time (see Section 2.1 for details).

${ }^{6}$ The Basel II standard approach allows for the use of external ratings to determine capital requirements. However, the German market for corporate bonds is very small; hence, very few companies have an external rating. We exclude a small number of standard-approach loans to these companies to ensure that all loans under the standard approach in our sample are subject to a fixed capital charge.
} 
(SA) regulatory approach for other portfolios when the financial crisis occurred.

We take advantage of this variation of the regulatory approach within IRB banks to identify the effect of pro-cyclical capital regulation on lending. At the time of the Lehman collapse in September 2008, IRB banks had only a portion of their loan portfolios transferred to the IRB approach. While the crisis event resulted in an unexpected increase in credit risk in Germany, it had an impact on the capital charges of the IRB loan portfolios only. ${ }^{7}$ The capital charges on SA loan portfolios within IRB banks were not affected by this event. By comparing the relative change in lending to firms that take a loan from at least two different IRB institutions - one where the particular loan is in a business segment that is using the IRB approach and another where the loan is in a business segment that is still using the standard approach-we can systematically control for differences between banks that introduced the new approach and banks that did not. Simultaneously this strategy allows us to control for firms' demand for credit, which might also be affected by the recession. ${ }^{8}$

Our identification strategy provides us an unbiased estimate of the pro-cyclicality effect as long as there is no relationship between the order in which IRB banks shifted their loan portfolios toward the new regulatory approach (IRB) and the banks' decision to adjust these loans in response to a crisis. There are two potential determinants of the order in which loan portfolios are shifted toward IRB within banks. First, the regulator requires that the bank has a sufficient amount of data to calibrate a meaningful credit risk model for a certain portfolio before it is shifted to IRB. Hence, banks are likely to start with loan portfolios in business segments where they are relatively active. We find that loans in business segments where the bank is more active are adjusted less over the crisis; this means that any bias would work against finding a significant impact of the regulatory approach. Second, if they were free to choose, banks would have an incentive to shift the least risky portfolios to the new approach first (since the reduction in capital charges is the highest for these portfolios).

\footnotetext{
${ }^{7}$ The average probability of default (PD) in our sample increased by 3.5 percent over the crisis period. Correspondingly - as the PD is a key factor in the determination of capital charges under the IRB approachcapital requirements rose by 0.54 percentage points on average.

${ }^{8}$ The identification strategy to isolate loan supply shocks from firm demand shocks by focusing on borrowing by a given firm from different banks is based on Khwaja and Mian (2008) and has been applied by Jiménez et al. (2013a).
} 
We find that banks tend to reduce the riskiest instead of the least risky loans over the crisis. Again, any bias would work against us. Finally, banks had to announce the order in which loan portfolios would be transferred toward IRB years before the outbreak of the financial crisis. ${ }^{9}$ Hence, they were unable to react to the crisis by changing the order of portfolios that are moved to the new approach.

We find that capital regulation has a strong and economically meaningful impact on the cyclicality of lending. Loans to the same firm by different IRB banks are reduced by 3.7 percent more over the crisis event when internal ratings (IRB) instead of fixed risk weights (SA) are used to determine capital charges. These findings are robust to the inclusion of bank and firm fixed effects in first differenced data. Further, there is no difference in the adjustment of loans using the standard approach provided by IRB banks or SA banks to the same firm. Both of the above results illustrate that our findings are not driven by bank heterogeneity.

We are also able to identify the effect of the Basel II capital regulations on the procyclicality of the aggregate supply of loans to firms. That is, we examine whether the adoption of the IRB approach makes it more difficult for firms to borrow from any source. On the one hand, it could be that a firm with IRB loans that were reduced during the crisis can offset the effect by increasing its borrowing from banks using the standard approach. On the other hand, if banks tend to ration especially large loans, the magnitude of the pro-cyclical effect on aggregate firm borrowing could be even larger. If this is the case, then the new capital regulations have important and, perhaps, undesirable macroeconomic implications.

The effects on aggregate firm borrowing are difficult to identify because there is only one observation per firm (borrowing from all of its banking relationships). ${ }^{10}$ It would not be possible to estimate the influence on firm borrowing if firms for which all loans are under the standard approach (or firms for which all loans are from SA institutions) differ systematically from firms with loans under the IRB approach. To surmount the problem, we

\footnotetext{
${ }^{9}$ Banks and the regulator had to agree on an implementation plan that specified an order according to which loan portfolios were transferred to IRB (see Bundesbank 2005). German banks that introduced the new approach submitted these plans to the regulator in 2006. Note that no individual loans could be shifted and that there could be no reversal of this choice.

${ }^{10}$ This means that it is not possible to use firm fixed effects to hold firm demand constant.
} 
restrict the sample to firms that have loans from IRB banks where some loans are under IRB to determine capital charges while others are still under the standard approach. We show that aggregate loan supply to a firm is reduced more during the crisis when the share of its loans from IRB institutions subject to IRB capital charges is greater. Specifically, we find that a firm that borrowed only with IRB loans experienced a reduction in total loans that is about 5 to 10 percent larger than the reduction for a firm that borrowed only with loans under the standard approach. This finding also holds if we restrict the sample to firms that have both SA and IRB loans from IRB banks. During economic downturns, it seems to be difficult for firms to offset reductions in lending from one bank by increasing borrowing from other banks. We find only weak evidence that firms that had more IRB loans experienced greater increases in capital costs. This suggests that IRB banks adjusted loan quantities rather than loan conditions as a reaction to the crisis.

Exploiting the cross-sectional heterogeneity of bank capital ratios before the crisis allows us to further nail down the channel through which capital regulation affects lending. IRB banks with a low equity ratio had a small buffer to absorb increases in capital charges induced by an increase in credit risk. Therefore, the IRB effect documented above should be particularly pronounced for these banks. We find that-among IRB banks-those institutions with a lower than median initial capital ratio prior to the crisis reduce their IRB loans by 2.9 percent more, relative to those with a higher than median capital ratio.

In additional tests we find that IRB banks reduce loans to which they have a large exposure relatively more. In particular, IRB banks reduce the IRB loans to which they have a larger than median exposure by 9.7 percent more than their smaller IRB loans. They also reduce loans more to those firms that experienced a higher deterioration of model-based credit risk estimates during the crisis. In both instances this supports our claim that banks had to deleverage in order to fulfill higher capital requirements. They do so by reducing particularly those loans for which they can save the most in required capital: i.e., larger and risker loans.

Our paper is the first to provide these direct empirical estimates of how the procyclicality inherent in the model-based approach to capital regulation affects the supply 
of loans to firms. Previous studies used numerical simulations on hypothetical or real-world portfolios (Carling et al. 2002, Corcóstegui et al. 2002, Lowe and Segoviano 2002, Kashyap and Stein 2004, Saurina and Trucharte 2007, Francis and Osborne 2009, Andersen 2011) or analyzed the overall effect of business cycle fluctuations on banks' capital buffers (Ayuso et al. 2004, Lindquist 2004, Jokipii and Milne 2008). While these studies find that the bank capital buffers fluctuate counter-cyclically, they cannot causally quantify how pro-cyclical capital regulation affects the supply of loans to firms. There are two recent papers that examine the effect of changes in capital requirements on bank lending. First, and most closely related to our own paper, Jiménez et al. (2013b) examine the effect of dynamic provisioning rules on bank lending in Spain. Exploiting variation across banks, they show that lowering capital requirements when economic conditions deteriorate helps banks to maintain their supply of credit. Our paper, in contrast, focuses on the effect of risk-based capital regulation on lending in the context of a shock to credit risk. Second, Aiyar et al. (2012) exploit a policy experiment in the United Kingdom and show that regulated banks, as compared with nonregulated banks, reduce lending in response to tighter capital requirements. Our loan-level data allow us to more directly address issues of firm-level and bank-level heterogeneity.

Our findings are in line with theoretical evidence on the pro-cyclicality of risk-based capital regulation, such as the dynamic equilibrium model of Repullo and Suarez (2012), which shows that increasing capital charges in a downturn can lead to a severe reduction in the supply of credit. Heid (2007) presents a macroeconomic model of the banking industry and shows that pro-cyclical capital charges can significantly affect lending even when banks are not capital constrained. ${ }^{11}$ Earlier, Thakor (1996) argued that small increases in riskbased capital requirements lead to large reductions in aggregate lending. ${ }^{12}$ Also, policy analysts have argued that the the Basel II model-based approach would increase the procyclicality of bank capital (e.g., Borio et al. 2001, Goodhart et al. 2004, and Gordy and Howells 2006).

Our paper also relates to the broader literature analyzing the impact of banks' liquidity

\footnotetext{
${ }^{11}$ See also Catarineu-Rabell et al. (2003).

${ }^{12}$ Berger and Udell (1994) provide empirical evidence that the introduction of Basel I exacerbated a credit crunch in the United States by inducing banks to shift into assets with lower capital charges.
} 
or capital shocks on loan supply (Bernanke 1983, Bernanke et al. 1991, Kashyap and Stein 2000). Peek and Rosengren (1995a,b) and Gambacorta and Mistrulli (2004) find evidence to support the concern that low-capitalized banks are forced to cut their loan supply during a recession. Peek and Rosengren $(1997,2000)$ go a step further by showing that capital shocks to Japanese banks in the 1990s induced them to cut back lending in the United States and that the resulting loan supply shock negatively affected real economic activity. For the recent crisis, Ivashina and Scharfstein (2010), Puri et al. (2011), Iyer et al. (2013), Kahle and Stulz (2013), and Paravisini et al. (2013) document a credit crunch. Our paper combines these different strands of the literature by showing that a tightening of capital requirements caused by pro-cyclical regulation affected lending in Germany after the Lehman collapse and that this had severe consequences for firms' overall access to funds.

Our findings illustrate how microprudential and macroprudential goals of banking sector regulation might conflict with one another. ${ }^{13}$ On the one hand, the reduction in lending we document is due to capital charges that are based on improved evaluation of credit risk. In terms of safety of the individual bank, it might make sense to extend fewer loans when economic conditions deteriorate. Following this logic, Repullo and Suarez (2012) suggest that the business cycle side effects of Basel II may have a payoff in the long-term solvency of the banking system. On the other hand, as banks simultaneously restrain their lending, firms' access to funds becomes restricted, and such restriction might negatively affect firmlevel investment and exacerbate the initial cyclical shock. In order to evaluate the welfare effects of pro-cyclical capital regulation one would have to evaluate both its impact on the long-term safety of the banking sector and its effect on credit supply in economic downturns. While we cannot make a statement on the former, our findings help to quantify the latter. We are the first to identify a causal effect of model-based regulation on lending in a recession and to present estimates of the large pro-cyclical effect, thus filling a void in the literature (see, e.g., Drumond 2009).

Basel III tries to account for both sides of the trade-off described above: while it con-

\footnotetext{
${ }^{13}$ See Galati and Moessner (2012) for a survey of the literature on macroprudential regulation. Recent contributions from the academic side include Kashyap et al. (2008), Brunnermeier et al. (2009), Hellwig (2010), Hanson et al. (2011), and Acharya et al. (2012).
} 
tinues to rely on risk-based regulation and the incentives such regulation provides for banks, macroprudential policy instruments like the countercyclical capital buffer were introduced with the explicit goal of smoothing credit supply over the cycle. Although our findings could be interpreted as a justification for such measures, we hesitate to draw specific policy conclusions. Our conjectures are reserved for our concluding remarks (Section 6). We question whether a countercyclical capital buffer would have been useful in the presence of a severe unexpected shock to credit risk such as the one analyzed here.

The remainder of the paper is structured as follows: In Section 2 we describe our data set and explain both the structure of the Basel regulations and the German institutional framework. Section 3 develops our empirical framework and explains our identification method. Section 4 presents our main results. Further robustness checks are in Section 5. The last section concludes and discusses the implications of the results.

\section{Institutional background and data}

In this section we outline the framework governing the determination of capital charges. We begin with an explanation of the relevant aspects of the Basel II agreement and the arrangements for its introduction in Germany. We then describe our underlying data set and present descriptive statistics.

\subsection{Introduction of risk-weighted capital charges}

The original Basel agreement (Basel I) introduced risk-based capital charges for the first time in 1988. First, bank assets were assigned to several risk groups (referred to as buckets) that received different risk weights. Second, regulatory capital requirements were defined in terms of risk-weighted assets, which were calculated as the total amount of each asset multiplied by its risk weight. For example, AAA-rated sovereign debt had a risk weight of 0 percent (i.e., no regulatory capital was required for such holdings), while all corporate loans had the same risk weight, 100 percent (Basel Committee on Banking Supervision 
1988). A drawback of this regulatory framework was that banks had an incentive to hold the riskiest assets within each risk group, as these provided the highest yield while being subject to the same capital charges as less risky assets in the same bucket. ${ }^{14}$ Therefore, an important motive for the introduction of Basel II capital standards was the wish of regulators to establish a stronger link between capital charges and the actual risk of each asset.

Basel II assigns an individual risk weight to each loan so that the capital charge reflects the underlying risk of the loan. Minimum capital requirements form the basis of the first of three pillars of the regulatory framework and allow banks to choose among two broad methodologies to calculate their capital charges for credit risk (Basel Committee on Banking Supervision 2006). ${ }^{15}$ First, the standard approach (SA) is similar to the old Basel I framework and automatically assigns a risk weight of 100 percent to corporate loans if the borrower has no external rating. If a firm's debt is rated by an external agency, the rating can be used to determine capital charges for loans to the firm. In Germany, the corporate bond market is extremely small, and therefore only very few firms have external bond ratings. We exclude from our sample SA loans to firms with ratings. ${ }^{16}$ Therefore, all SA loans considered in our analysis are automatically assigned a risk weight of 100 percent independent of the riskiness of the loan.

Second, if banks fulfill certain conditions and disclosure requirements they can opt for the internal ratings-based (IRB) approach that relies on the banks' own risk estimates to determine risk weights for assets. ${ }^{17}$ IRB requires the estimation of four parameters to determine the risk weight of a loan: the probability of default (PD), the loss given default, exposure at default, and the effective maturity of the loan. The higher the estimate for any of these parameters, the higher the risk weight that is attributed to the loan. In the advanced internal ratings-based approach, the bank provides estimates for all of them, while

\footnotetext{
${ }^{14}$ The effects of Basel I on bank behavior are analyzed in Basel Committee on Banking Supervision (1999).

${ }^{15}$ Minimum capital requirements under Basel II are designed to address credit risk, operational risk, and market risk. The other two pillars of Basel II are a better supervisory review and a stronger focus on market discipline.

${ }^{16}$ Only 149 firms in our sample have an external bond rating. These firms consitute 0.1 percent of all firms in our sample, or 2.1 percent of the firms used in our main identification test (Test 3, see Section 3).

${ }^{17}$ See Solvabilitätsverordnung (2006), $\S \S 56-59$ for the requirements that banks have to fulfill to be eligible for IRB.
} 
in the basic internal ratings-based approach the bank estimates the only PD, and standard values are assumed for the others. ${ }^{18}$ No matter whether a bank applies SA or IRB, the Basel agreement requires that aggregate capital charges must be no lower than 8 percent of risk-weighted assets.

Since the organizational efforts as well as the administrative expenses for the introduction of the new approach are high, the main determinant of a bank's decision to opt for IRB is its size. Large banks have the ability to distribute the administrative costs over a larger number of loans. Moreover, banks are incentivized to become IRB institutions by the fact that capital requirements are substantially lower under IRB than under SA (Basel Committee on Banking Supervision 2006, p. 12). ${ }^{19}$ Since banks that decide to become IRB institutions may have an incentive to report low PDs for their loan portfolios in order to economize on regulatory capital charges, the introduction of IRB is closely monitored by the regulator. The regulator requires that the PDs used for the determination of capital charges are the same as the ones that the bank uses in order to determine loan conditions (e.g., the interest rate). Thus, if a bank were to consistently report smaller PDs in order to save on regulatory capital, the bank would eventually hurt itself by mispricing its loans.

For our analysis the crucial difference between the two approaches is that capital charges are endogenous to credit risk with IRB but not with SA. For loans under SA, risk weights are determined when the loan is made and do not change. For loans under IRB, the risk weights are determined by the $\mathrm{PD}$, which can change as the firm's underlying condition changes. The internal risk models used by German banks estimate PDs at each point in time rather than taking an average over the business cycle. Thus, during an economic downturn PDs are likely to increase, implying higher capital charges if the bank is using IRB. The pro-cyclicality of capital charges under Basel II is one of its most controversial features. In this paper we analyze the effects of pro-cyclical capital charges on banks' lending be-

\footnotetext{
${ }^{18}$ We do not distinguish between the advanced and basic internal ratings-based approaches in our empirical analysis, because the risk weight depends on the loan's PD in both cases.

${ }^{19}$ At the beginning of our sample period in the first quarter of 2008 , the mean risk weight for loans from IRB banks was 43.7 percent: i.e., a loan with a face value of $€ 100$ increased risk-weighted assets by only $€ 43.70$ on average (see Panel B of Table 1). Considering that risk weights for corporate loans were equal to 100 percent under Basel I this indicates that IRB institutions experienced a substantial reduction in required capital for corporate lending following the Basel II reform.
} 
havior. The analysis depends on our ability to distinguish the effect of pro-cyclical capital charges from other determinants of lending behavior. Our identification approach exploits the gradual introduction of IRB by German banks.

The introduction of IRB is a highly regulated process that is laid out in the Solvabilitätsverordnung (2006), §56. In order to deal with the operational complexity of introducing new rating models, banks do not apply the new approach to all loans at once; rather, they agree on a gradual implementation plan with the regulator. ${ }^{20}$ The phased rollout of IRB means that during the transition, which typically lasts for several years, banks will have both IRB and SA loans in their portfolios. Furthermore, the regulator requires banks to introduce IRB not for individual loans but for the entire loan portfolio of a given business unit that can be evaluated with a given internal rating model. Once a rating model has been put in place, the capital charges for all loans in the business unit arising from existing or new customers are determined with the consistent use over time of the same rating model. ${ }^{21}$ Thus, loans in certain business units or asset classes have to be shifted all at once, so that it is not possible for the bank to strategically shift individual loans from one approach to the other.

The implementation plan specifies an order according to which IRB is applied to the different business units (loan portfolios) within the bank. The regulator requires banks to start by implementing IRB for those business units that have sufficient data on past loan performance available to calibrate a PD model. Consequently, banks have started with loan portfolios in industry segments where they are relatively active. Further, the bank and the regulator agree on the implementation plan for business units and the timing of the rollout years before the actual introduction. The German banks that adopted IRB had submitted their implementation plans to the regulator in 2006. Hence, they were not able to react to the financial crisis by changing the order of loan portfolios that were transferred to IRB

\footnotetext{
${ }^{20}$ See Solvabilitätsverordnung (2006), $\S \S 64-67$ for details on the implementation plan. Banks adopting the new approach must show on application that at least 50 percent of their risk-weighted assets will be calculated on the basis of IRB (entrance threshold). Furthermore, the implementation plan has to specify how the bank will achieve 80 percent IRB coverage within two and half years after the introduction (regulatory reference point) and 92 percent IRB coverage five years after the introduction (exit threshold).

${ }^{21}$ See Solvabilitätsverordnung (2006) $§ 57,3$.
} 
or by applying the standard approach to IRB portfolios after loan PDs deteriorated. At the outset of our data sample in 2008Q1 the phase-in of business units using IRB was underway. Thus, capital charges for IRB banks were determined by the internal ratings-based approach for some parts of the loan portfolio and by the standard approach for other parts. We exploit this within-bank variation for our identification strategy as explained in Section 3.

\subsection{Data and descriptive statistics}

Our principal source of data is the German credit registry compiled by the Deutsche Bundesbank. As part of its supervisory role, the central bank collects data each quarter on all outstanding loans of at least $€ 1.5$ million. The dataset includes information on the lender's and the borrower's identity, the amount of the loan outstanding, the regulatory approach used by the bank, the probability of default (PD), and the risk-weighted assets corresponding to the respective loan. We combine these data with annual information from bank balance sheets obtained from the Bundesbank's BAKIS database.

Our sample includes 1,825 commercial banks, state banks and cooperative banks. ${ }^{22}$ We restrict the analysis to those commercial loans for which we are able to determine the regulatory approach used at the beginning of our sample period in $2008{ }^{23}$ We consider a loan to be an IRB loan if the bank adopted the approach for the loan in either the first or second quarter of 2008. ${ }^{24}$ To control for potential differences between IRB banks and SA banks that might have an impact on lending, we separate our sample into those banks using the internal ratings-based approach during our sample period and those banks not using it. As can be seen in Panel A of Table 1, there are 1,784 SA banks and 41 IRB banks in our sample. On average, IRB banks had adopted the new approach for 62 percent of their loans

\footnotetext{
${ }^{22}$ We exclude loans from finance companies, stock brokerage firms, and other special purpose institutions.

${ }^{23}$ Although Basel II in Germany was introduced in January 2007, detailed information on the regulatory approach applied to a certain loan as well as PD estimates that we need for our analysis became available to the regulator only in 2008.

${ }^{24} \mathrm{As}$ the implementation period for the internal ratings-based approach may last for up to five years it is possible that certain loans that we classify as SA loans are switched to IRB at a later point during our sample period. The opposite case, however, cannot occur since IRB banks are not allowed to switch IRB loans back to SA. Loans switched to IRB at later point in time would—if anything-prevent us from finding a significant impact of the regulatory approach on lending as they simply add noise.
} 
at the onset of our sample period in early 2008 (Share IRB). As expected, IRB banks are much larger and have lower equity ratios than SA banks. Regarding profitability, measured by ROA, there are no substantial differences between the two groups. There are relatively more commercial banks among the group of IRB banks, while most cooperative banks continue to use the standard approach. These differences between SA and IRB banks pose potential problems for identification as the two groups might have been affected differently by the crisis event (e.g., owing to different degrees of internationalization or differences in capitalization). Our estimation strategy allows us to systematically address these important identification issues.

Descriptive statistics for the loan data are shown in Panel B of Table 1. Overall, our sample contains 182,966 loans to 107,025 distinct firms for the period from the first quarter of 2008 through the third quarter of 2011. The size of the average loan in our sample is $€ 16.1$ million. Although there are many more SA banks than IRB banks, the total number of loans extended is approximately the same for each group as IRB banks have many more loans on average. Of the 182,966 loans, 49.5 percent are granted by IRB banks and 33.6 percent are subject to the internal ratings-based approach. There are more loans from IRB banks than loans that are subject to the internal ratings-based approach because IRB banks had not yet shifted all their loan portfolios to the new approach at the onset of our sample period (see Section 2.1). ${ }^{25}$

As noted earlier, our empirical approach will examine lending behavior in the context of a specific crisis event, the Lehman failure in September 2008. That is, our variable of interest will be the difference between (the log of) average lending in the post-crisis and pre-crisis periods. Average loan balances fell by almost 4 percent over the crisis period. The average PD reported by banks to the regulator before the crisis was 4.1 percent and increased to 7.8 percent over the crisis. ${ }^{26}$ For IRB loans an increase in PD translates into an increase

\footnotetext{
${ }^{25}$ Specifically, our sample contains 90,500 loans from IRB banks. Of these loans, 61,417 are subject to IRB, while the remaining 29,083 are still subject to the standard approach.

${ }^{26}$ According to Basel Committee on Banking Supervision (2006), PD estimates should reflect the probability of a default event for the loan over the next 12 months. Note that we have information on changes in PD for 64,880 of the 182,966 loans in our sample. These are more than the 61,417 IRB loans in our sample, as the regulator asks IRB institutions to report PDs also for SA loans in cases where they estimated PDs for internal purposes.
} 
in the risk-weighted assets (RWAs) of the loan (i.e. the loan amount multiplied with its risk weight). The average ratio of RWAs to loans was 43.7 percent before the crisis but increased by 6.7 percent over the crisis. Hence, an increase in PD results in a disproportionally large increase in the ratio of RWAs to loans. Regulatory capital requirements are 8 percent of riskweighted assets; accordingly, capital charges for IRB loans increased by 0.54 percentage points on average (6.7 percent $\times 8$ percent). By definition, capital charges for SA loans are not affected by changes in default probabilities.

We also match our loan data with accounting information for German firms from the Bureau van Dijk's Amadeus database to obtain more detailed firm-level information. The Bundesbank credit register and the Amadeus accounting information were hand-matched by company name and location. Matches were made for 7,778 firms. Descriptive statistics for firms in the matched sample are provided in Panel $\mathrm{C}$ of Table 1. The average firm in the matched sample is rather large, with total assets of $€ 153.4$ million. Further control variables are the firm's pre-event profitability (measured by its ROA) and leverage (defined as total debt over total assets). We use a credit risk model developed by Förstemann (2011) that applies firm balance sheet information in order to calculate firm-specific PDs that are similar to estimates obtained from Moody's RiskCalc model. ${ }^{27}$ In Section 4.2, we investigate how aggregate firm loans change over the crisis. Total firm loans were $€ 22.7$ million prior to the crisis and declined by 7.8 percent on average following the event. ${ }^{28}$ Remarkably, the decline in total firm loans is about twice the size of the decline in the average loan. Following the crisis event banks reduce particularly those loans to which they have a large exposure. Finally, firm capital costs are defined as aggregate interest expenses over total loans. The overall interest rate for the average firm was about 8.3 percent in early 2008 and did not change much over the crisis, although the standard deviation of 2 percent for the change variable suggests that there was some variation across firms. ${ }^{29}$

\footnotetext{
${ }^{27}$ See Förstemann (2011) for details. Estimates from the credit risk model are smaller than loan-specific PDs reported by banks on average, as the credit risk models rely exclusively on accounting information.

${ }^{28}$ We calculate total firm loans by aggregating all the firm's loans in our sample.

${ }^{29}$ As our capital cost measure is a rather crude approximation we exclude implausible observations, in particular those observations where the absolute change in capital costs over the crisis was greater than 5 percentage points. Results in the empirical section do not depend on the choice off the cutoff point and are robust to using a higher cutoff.
} 


\subsection{Graphical analysis of the impact of the financial crisis on banks' capital charges}

Before we present our methodology for identifying changes in loan supply, we provide a graphical analysis of the impact of the financial crisis on banks' capital charges for IRB loans. Figure 1 shows that a slowdown in German GDP growth began before 2007. However, a severe contraction followed the Lehman shock in 2008Q3, resulting in negative GDP growth rates until 2010Q1. We are interested in the impact of this severe real shock on bank capital charges on IRB loans.

As documented in the descriptive statistics above, the crisis slowdown was associated with a rise in capital charges per euro lent for IRB loans. The average ratio of RWAs to loans rose by about 6.7 percent for the IRB loans which translates into an increase in capital charges of 0.54 percentage points. Panel A of Figure 2 illustrates how aggregate IRB loans and the associated RWAs evolved during the crisis event. ${ }^{30}$ Total RWAs are relatively constant throughout the period (they rise slightly after the crisis event until the second quarter of 2009 and decrease slightly thereafter). In contrast, the aggregate volume of IRB loans drops sharply after the crisis event as banks reduce their IRB lending exposure. This observation is consistent with the increase in the risk weight for the average loan documented above. The right graph shows the ratio of total RWAs to the total amount of loans; the increase in risk weights is also present on aggregate. The ratio increases sharply until the second quarter of 2009. Subsequently, it declines for about a year and then levels off. ${ }^{31}$

The figure shows that banks have to hold more capital for the same amount of IRB loans following the crisis event. This pattern illustrates the pro-cyclical effect of capital charges: during a recession the bank has to reduce its lending in order to keep capital charges constant. The subsequent drop in the ratio of RWAs to loans can most likely be explained by adjustments in banks' loan portfolios: as banks were forced to deleverage in order to ful-

\footnotetext{
${ }^{30}$ Aggregate RWAs are calculated as the sum of the outstanding loan amounts multiplied by their respective risk weights. Recall that our sample includes all lending relationships that existed in the second quarter of 2008 , so relationships that originated after the crisis event are not included in the aggregate series.

${ }^{31}$ The ratio of aggregate RWAs to aggregate loans is somewhat lower than the average ratio of RWAs to loans (see Table 1), as larger loans tend to have lower risk weights.
} 
fill capital requirements, they reduced particularly those loans whose risk weights increased most over the crisis. In order to provide evidence for this interpretation, we show the evolution of total RWAs under the assumption that banks do not adjust the quantity of their loan portfolios. To do so, we calculate a hypothetical series of RWAs by multiplying the observed risk weight for each loan in each period by the loan amount in 2008Q3, and then aggregate these amounts in each quarter. Since we cannot observe risk weights for loans that were canceled or matured before the end of our sample period, we consider only loans that existed throughout the entire sample period. ${ }^{32}$ The results of this exercise are shown in Panel B of Figure 2. The right graph shows the ratio of the hypothetical RWAs series to the total amount of loans in 2008Q3. Its development over time illustrates that if banks had not adjusted their IRB loan portfolios following the crisis shock, the RWAs/loans ratio would have continued to rise throughout the period.

Figure 2 offers strong evidence of a pro-cyclical effect of risk-weighted capital charges on banks' loan supply. To rule out the possibility that this effect is driven by banks' heterogeneity or changes in firms' loan demand, we will introduce our identification methodology in Section 3.

\section{Methodology}

\subsection{Identifying changes in loan supply}

Our identification strategy exploits the gradual introduction of IRB as described in Section 2.1. Loans in our sample fall into one of the following three groups (see Figure 3). First, all loans provided by SA banks remain under the standard approach. Thus, the required capital charges of these loans do not depend on their credit risk. ${ }^{33}$ Second, loans by IRB banks can be subject to IRB if the loan is part of a portfolio that had been moved to the new approach at the onset of our sample period. Third, loans by IRB banks that had not

\footnotetext{
${ }^{32}$ Note that the exclusion of loans that were canceled or not rolled over by banks is likely to bias against finding an increase in the RWAs/loans ratio.

${ }^{33}$ As stated in Section 2, there are no SA loans with an external rating in our sample.
} 
yet been moved to IRB remain under the standard approach. The distinction between these three classes of loans provides the foundation of our identification strategy.

We start by examining changes in lending by SA and IRB banks in the context of the crisis event. Following Khwaja and Mian (2008), we consider how lending by IRB banks changed in comparison with lending by SA banks to the same firm (Test 1). The within-firm comparison is important because firm-specific loan demand is likely to be affected by the event. We define a variable Share IRB that is equal to the percentage share of all loans of the bank that are subject to the IRB approach (i.e., it takes the value zero for SA banks). Alternatively, we use a dummy variable to indicate whether or not an institution has opted for IRB. Thus, Test 1 is based on firms that have at least two loans-one loan from an SA bank and one loan from an IRB bank, or two loans from distinct IRB banks. ${ }^{34}$ Formally, we estimate:

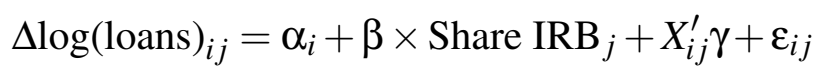

The dependent variable is the change over the crisis event in the logarithm of loans from bank $j$ to firm $i$. In order to avoid problems of serial correlation we collapse our quarterly data into single pre- and post-event time periods by taking time-series averages of loans (Bertrand et al. 2004). ${ }^{35}$ Thus, there is one observation per firm-bank relationship. The equation includes firm fixed effects $\alpha_{i}$. In particular this means that identification of our coefficient of interest- $\beta$, the coefficient on the share of IRB loans within a bank-comes only from variation within the same firm. Our test shows whether the same firm, borrowing from two different banks, experiences a larger decline in lending from banks that use IRB for a larger share of their loans. Control variables $X_{i j}$ include pre-event size, capitalization and profitability of the bank, a set of dummy variables indicating the bank's type, and the share of bank $j$ 's loans in firm $i$ 's two-digit SIC industry sector. To account for potential correlation among changes in loans from the same bank we cluster standard errors at the bank level in all our regressions.

\footnotetext{
${ }^{34}$ Our sample contains 20,740 firms that have at least one loan from an SA bank and one loan from an IRB bank or two loans from distinct IRB banks. Overall, these firms have 93,370 loans, which separate into 44,423 SA loans and 48,947 IRB loans (Table 1, Panel D).

${ }^{35}$ We could also estimate Equation (1) without time-collapsing the data if we replace the firm fixed effects with firms times quarter fixed effects. Results from this specification are qualitatively very similar.
} 
Interpreting $\beta$ from Equation (1) as the impact of credit risk-specific capital charges on lending behavior might be problematic if banks that provide more IRB loans differ systematically from banks that provide more (or only) SA loans. We have shown already that IRB institutions tend to be systematically larger, have lower capital ratios, and are more likely to be privately owned (Table 1, Panel A). Thus, our main concern is that IRB banks were also internationally more active and therefore more affected by the global crisis. Clearly, if IRB institutions generally experienced a larger crisis shock than SA institutions, this could explain why banks with larger shares of IRB loans reduced their lending significantly more than banks with lower shares. ${ }^{36}$ However, as we explained before IRB banks did not introduce the IRB approach for all loans at the same time. Consequently, not all their loan portfolios were subject to potentially higher capital charges following the recession. To address concerns regarding the banks' heterogeneity, we exploit this feature by introducing two additional tests.

First, we test whether IRB banks' SA loans and SA institutions' loans are affected differently by the crisis event. Neither the SA institutions' capital charges nor those for IRB banks' SA loans are affected by an increase in firms' credit risk. Thus, by comparing the lending reaction of SA banks' SA loans with IRB banks' SA loans, we can test whether the IRB effect estimated in Test 1 is driven by bank heterogeneity. For Test 2 we use a subsample restricted to firms that obtain at least two SA loans from separate institutions that differ in the share of IRB loans they hold in their aggregate loan portfolio (see Figure 3 for an illustration). ${ }^{37}$ We then estimate Equation (1) for this subsample of loans. ${ }^{38}$ If we find $\beta$ to be close to zero in Test 2, we conclude that the treatment group and the control group are not systematically different from each other and that the effect identified in Test 1 is indeed due to the choice of the regulatory approach rather than the characteristics of the banks.

\footnotetext{
${ }^{36}$ Equation (1) includes bank size, capital ratio, and ownership as control variables and hence also directly controls for the influence of these variables on banks' lending behavior.

${ }^{37}$ In our sample 10,496 firms have at least one SA loan from an SA bank and at least one SA loan from an IRB bank or two SA loans from distinct IRB banks. These firms have a total of 49,492 SA loans, of which 35,852 are from SA banks and 13,640 are from IRB banks (Table 1, Panel D).

${ }^{38}$ Again, we use the dummy variable $D($ IRB bank) instead of Share IRB in an alternative specification. Essentially, this means that we examine the relative change in lending to firms that have at least one SA loan from an SA bank and another SA loan from an IRB bank.
} 
Second, we can test for the IRB effect within the group of IRB banks only and thereby systematically control for bank heterogeneity. For Test 3 (see also Figure 3) we restrict the sample to firms that borrow from more than one IRB bank. In particular, we require that the firm has at least one IRB loan and at least one SA loan from different IRB institutions. ${ }^{39}$ Formally, we estimate:

$$
\Delta \log (\operatorname{loans})_{i j}=\alpha_{i}+\alpha_{j}+\delta \times \mathrm{D}(\operatorname{IRB} \operatorname{loan})_{i j}+X_{i j}^{\prime} \gamma+\varepsilon_{i j}
$$

where $D($ IRB loan $)$ is a dummy variable that takes the value 1 if the loan is subject to the IRB approach. In contrast to Tests 1 and 2 we include bank fixed effects $\alpha_{j}$ in addition to firm fixed effects $\alpha_{i}$ to systematically control for bank heterogeneity. This means that identification in Equation (2) is based on within-bank variation (compare with Jiménez et al. 2013a). The test shows whether the same firm-borrowing from two different IRB banksexperiences a larger decline in lending for loans that use the IRB as compared with the standard approach

\subsection{Selection of IRB portfolios}

Test 3 provides us with an unbiased estimate of $\delta$ as long as the choice of the loan portfolios whose capital charges are determined by IRB within IRB banks at the outset of our sample period is not endogenous to a bank's decision to adjust these loans in a different way from other loans as a response to a crisis. We rule out concerns that this results in an absolute upward bias of $\delta$, for two reasons. First, if the regulator allows a bank to decide on the order in which loan portfolios are shifted toward IRB, the bank would have an incentive to select the least risky portfolios first (the least risky portfolios would yield the lowest average PDs, and for these portfolios the reduction in capital charges due to the shift to IRB would be the greatest). We observe, however, that banks tend to reduce the outstanding amount of the least risky portfolios relatively less over a crisis. Thus, this selection concern would rather cause a bias against finding an IRB effect in Test 3. Second, the regulator requires

\footnotetext{
${ }^{39}$ In our sample 7,159 firms have at least one IRB and one SA loan from two different IRB institutions. These firms have a total of 27,620 loans: 9,226 SA loans and 18,394 IRB loans (Table 1, Panel D).
} 
banks to start with loan portfolios for which they have sufficient data in order to calibrate meaningful PD models (see Section 2.1). In doing so, the regulator respects the structure of banks' internal loan portfolios (which are generally based on industry classifications). ${ }^{40}$ Consequently, at IRB banks, the classification of a given loan as IRB or SA at the beginning of our sample period depends on whether or not the loan is in a business segment where the bank is relatively active. Thus, our results would be biased if banks reduced loan portfolios in segments where they are more active relatively more over the crisis. In the latter empirical analysis we will show that this is not the case; if anything, in business segments where they are more active, banks reduce portfolios relatively less over the crisis. To sum up, any bias resulting from the selection of loan portfolios within IRB banks would be against finding an IRB effect in Test 3.

We can substantiate our argument by empirically testing for the determinants of the IRB/SA loan classification within IRB banks at the onset of our sample period. In Table 2, we show estimates of a probit model to examine the role of loan-specific as well as portfoliospecific determinants of the observed IRB/SA classification. The dependent variable is a dummy variable equal to 1 if the loan is subject to IRB. To measure a bank's activity in a given business segment, we sum the bank's loans to firms within the respective two-digit SIC industry sector and divide them by all loans in our sample to firms within this industry sector (Loan share). Column 1 shows that Loan share is an important determinant for the IRB/SA classification within an IRB bank at the outset of our sample. In line with the argument from above, loan portfolios in segments where the bank is more active were shifted first toward IRB within IRB institutions. In order to measure the risk of a given loan portfolio, we calculate the average firm-specific PD in each two-digit SIC industry sector (Portfolio $P D) .{ }^{41}$ While the average risk of a loan portfolio enters the probit model negatively, the coefficient is not significant. In columns 3 and 4 we test for loan-specific determinants of the IRB/SA classification. Neither the loan size nor the firm balance sheet variables, such as

\footnotetext{
${ }^{40}$ See Bundesbank (2005) for details.

${ }^{41}$ We use firm-specific PDs, as the loan-specific PDs reported by banks are available (almost) exclusively for IRB loans so that we would miss counterfactual PDs for portfolios that were not transferred to IRB. Firmspecific PDs are from a matched sample that is explained in Section 2.2. They are on average a bit smaller than the PDs reported by banks, as they rely exclusively on accounting information.
} 
firm size, ROA, leverage, or PD, significantly affect the observed IRB/SA selection within IRB banks. When we include all explanatory variables at the same time (column 5), Loan share is the only significant determinant for the classification of loan portfolios. Therefore we will include this variable in our main empirical tests, in order to observe whether the selection may account for a bias.

\section{Empirical results}

\subsection{Loan-specific risk weights and lending}

In this section we present results for Tests 1 to 3 described above. As noted, the dependent variable for these tests is the change in the log of lending over the crisis period. Specifically, we collapse all available quarterly data for a given loan into pre- and post-crisis event periods and look at the difference. All regressions are estimated with firm fixed effects to control for unobserved heterogeneity in the firm's demand for credit. Results for the three tests are shown in Table 3.

We start by estimating Equation (1) to see whether, over the crisis, a given firm borrowing from different banks experienced a larger reduction in loans from banks with a high fraction of IRB loans in their portfolios (Test 1). ${ }^{42}$ Column 1 of Table 3 indicates that the larger the share of IRB loans within a bank, the more the bank reduces its lending relative to a bank with a lower share of IRB loans to the same firm. Since firm-specific credit demand shocks get absorbed by the firm fixed effects, the coefficient reflects differences in banks' credit supply. It is likely that banks were affected differently by the financial crisis, and therefore we add bank-level control variables in the estimates shown in column 2 . The coefficient for Share IRB is smaller but still significant. We can directly address potential selection concerns resulting from the order in which loan portfolios were shifted toward IRB by including the relative size of a loan portfolio (Loan share) as a control variable. The coefficient on Loan share is positive but not significant. If anything, in response to the

\footnotetext{
${ }^{42}$ Technically, a loan is included as long as the firm is borrowing from two or more institutions where the share of IRB loans differs (see Section 3).
} 
crisis event banks tend to adjust loans and hence loan portfolios less drastically in business segments where they are relatively active. Thus, the classification of loans to IRB portfolios would bias our estimates against finding a significant effect of the choice of the regulatory approach on changes in lending following the crisis.

In column 3 we replace the variable Share IRB with $D(I R B$ bank), a dummy variable that takes the value 1 if a bank decided to become an IRB institution and zero otherwise. Thus, we consider the relative change in lending for a firm that has at least one lending relationship with an SA institution and one with an IRB institution. Again, we find a significant relative reduction in lending from IRB compared with SA institutions. The IRB effect is also economically meaningful: if we apply the estimate from column 3, IRB banks reduce their lending by 3.1 percent more than banks that have only SA loans. ${ }^{43}$ These findings indicate that tailoring capital requirements to the risk of each individual asset based on an internal rating system increases the pro-cyclicality of lending.

Next, we turn to Test 2, where our sample includes SA loans made by both SA and IRB institutions. There are 10,496 firms that obtain SA loans from at least two different banks where the share of IRB loans differs. ${ }^{44}$ Test 2 will show us whether IRB banks reduce their lending uniformly or differentiate between IRB and SA loans. If the regulatory approach chosen for a specific loan was the driving force behind our findings for Test 1 , the estimate of $\beta$ in Equation (1) for this sample of SA loans should be zero. If banks that introduced IRB were more severely hit by the financial crisis and this outcome drove our findings for Test 1 , we should find a negative significant coefficient.

Results for Test 2 are shown in Table 3, columns 4 to 6. The share of IRB loans is significant when we do not control for bank characteristics (column 4). This implies that IRB institutions reduced their lending over the crisis more than SA institutions. However, this difference is driven by observable bank characteristics that are correlated with the choice of becoming an SA or an IRB institution. Once we control for these characteristics, the Share IRB coefficient is not significantly different from zero (column 5). This finding is also

\footnotetext{
${ }^{43}$ The effect is equal to $\exp (\beta)-1$ (Halvorsen and Palmquist 1980).

${ }^{44}$ These are all firms with at least two SA loans that are not only from SA institutions.
} 
robust to using a dummy variable indicating an IRB institution instead of the variable Share $I R B$ (column 6). As before, firm fixed effects absorb any firm-specific credit demand shocks and ensure that we are comparing changes in lending to a given firm. The comparison of Tests 1 and 2 supports our claim that it is indeed the regulatory approach that is responsible for the stronger reduction of loans from IRB banks.

To remove any remaining concern that our findings are driven by bank heterogeneity, we identify the effect of risk-specific capital charges on lending within IRB banks. Identification within IRB banks is possible, as these institutions had not yet switched all their loan portfolios to IRB before the crisis. Thus, the IRB banks have loans under IRB as well as loans under SA. Further, there are firms that have an IRB loan from one bank and an SA loan from another IRB bank. For Test 3, we restrict the sample to loans from IRB banks and investigate whether these banks reduced their IRB loans more than their SA loans during our sample period. Identification in the regression with firm fixed effects requires that the firm has at least one SA loan from an IRB bank and at least one IRB loan from an IRB bank. Our sample contains 7,159 firms with 27,620 loans that fulfill this condition (Table 1, Panel D). Results for Test 3 are reported in columns 7 to 9 of Table 3 and show a significantly negative coefficient for the IRB loan dummy. The effect is robust to the inclusion of bank-level control variables in column 8 and also economically significant: within the same firm, loans for which IRB is used are reduced by about 3.9 percent more than loans for which the SA approach is used. Since Test 3 is on the loan level, we can systematically account for bank heterogeneity by including bank fixed effects (column 9). We still find a significant effect of the regulatory approach on changes in lending to the same firm. ${ }^{45}$ This provides evidence that the regulatory approach used for a certain loan has a strong and economically meaningful influence on the extent to which the loan was "crunched" during the recent crisis. Increases in risk weights during economic downturns force capital-constrained banks that use the internal ratings-based approach to deleverage in order to fulfill their capital requirements (recall Figure 2). Results for Test 3 indicate that they do so by reducing

\footnotetext{
${ }^{45}$ The estimation strategy in column 9 is similar to the one developed by Jiménez et al. (2013a): while they use quarterly data and include time $\times$ firm and time $\times$ bank fixed effects, we collapse our data on the time dimension and therefore include firm and bank fixed effects (see Khwaja and Mian 2008).
} 
the very assets that caused the increase in capital requirements: loans that are subject to IRB. Loans that are subject to the standard approach, on the other hand, are relatively less affected.

Our findings so far focus on changes in the loan volume of existing lending relationships, which we call the intensive margin. We can also test whether IRB banks are more likely to end an existing relationship entirely if the loan is subject to IRB as compared with SA, the extensive margin. In columns 10 and 11 of Table 3 the dependent variable is a dummy variable equal to 1 for loans that existed in the second quarter of 2008 but that ceased to exist at some point following the crisis shock. The coefficient for $D$ (IRB loan) is positive, but insignificant, indicating that the effect of the regulatory approach is less pronounced on the extensive as compared with the intensive margin of lending. This is consistent with a finding by Jiménez et al. (2013b), who argue that the somewhat moderated effect on the extensive margin is due to a time lag, since lending relationships end only when all loans_-including those with a longer maturity_are fully repaid.

In Table 4 we replicate regressions from Table 3 using an ordinary least squares (OLS) specification without firm fixed effects. The main advantage of reporting OLS results is that it allows us to include firms that have only one bank relationship. We begin with OLS estimates that use only those firms that were included in the regressions in Table 3 to make our findings comparable (columns 1, 4, and 7). The coefficients remain relatively stable and are comparable to the coefficients from the fixed effects regressions in Table 3. Thus, firm loan demand does not appear to differ for firms borrowing from IRB or SA banks (or for IRB or SA loans within IRB banks). We next include single-relationship firms and firms that borrow only from SA institutions in columns 2, 5, and 8 of the table. For Test 1, the coefficient for the IRB variable (Share IRB) remains significant but increases from -0.058 to -0.030 . The effect of the regulatory approach seems to be less pronounced for single-bank firms. Singlerelationship firms are less able to replace IRB loans if lending terms deteriorate. ${ }^{46}$ Results for Test 3 point in the same direction: The coefficient for the IRB loan dummy increases from -0.050 in column 7 to -0.025 in column 8 . For Test 2 , the OLS specification does not

\footnotetext{
${ }^{46}$ In Section 4.2 we will investigate whether firms' loan costs actually increased over the crisis.
} 
find a significant difference between banks using the standard approach and banks using the IRB approach and hence confirms the finding from the fixed effects estimation. Finally, if we use Exit instead of the change in lending as a dependent variable, the coefficient for the IRB loan dummy is weakly significant in column 10, but becomes insignificant when bank fixed effects are added in column 11. Overall, the impression from Table 3 that the effect of the regulatory approach is moderated on the extensive margin is confirmed in Table 4.

\subsection{Capital regulation and firms' overall access to funds}

In the previous section we showed that - compared to SA loans - IRB loans were reduced relatively more over the crisis and that this effect was independent of any firm or bank characteristics. It is a priori unclear how this result would affect firms' overall access to funds. On the one hand, the OLS results with all firms showed that the reduction in the quantity of IRB loans is smaller for firms with a single banking relationship. That is, firms with multiple relationships may have some ability to compensate with other lending relationships (i.e., increase lending with SA loans when banks adjust their IRB loans). On the other hand, if larger loans are reduced relatively more, the magnitude of the documented pro-cyclical effect could be considerably larger at the aggregate firm level as compared with the individual loan level. In this section we turn our attention directly to the overall access to funds by firms. Did firms relying on IRB loans experience a stronger reduction in loan supply? The question is central for evaluating the real economic effects of capital charges based on credit-specific risks. In this section we examine how the regulatory approach used for loans affects the aggregate supply of loans to a firm and the average borrowing costs for the firm.

Importantly, firms that borrow (mostly) from IRB or SA banks might also differ in their loan demand over the crisis (e.g., owing to size differences). As we examine the change in firms' total outstanding loans during the crisis period, we have only one observation per firm and hence cannot include firm fixed effects. The variation in the IRB/SA loan classification within IRB banks during this period allows us to directly address this issue. Specifically, we restrict the sample to firms that have both SA loans and IRB loans from IRB banks and define a variable, Share (IRB-IRB loans), as the share of a firm's loans from IRB banks 
that are subject to the internal ratings-based approach. Firms in this subsample should be relatively similar, and this additional variable allows us to investigate whether-among these firms - those with a larger share of IRB loans experience a greater reduction in aggregate loans over the crisis. ${ }^{47}$

Using the matched firm sample for which we have balance sheet information, we are able to estimate the following firm-level equation:

$$
\Delta \log (\text { total firm loans })_{i}=\beta \times \text { Share }(\text { IRB-IRB loans })_{i}+X_{i}^{\prime} \gamma+\varepsilon_{i}
$$

The dependent variable is the difference in the logarithm of a firm's total loans over the crisis. As in the loan-level regressions we collapse our data into single pre-event and postevent time periods by taking time averages of a firm's total loans. The coefficient of interest is $\beta$, which shows how Share (IRB-IRB loans), the share of a firm's loans from IRB banks that are subject to the internal ratings-based approach, affects the change in the firm's total loans over the crisis. Firm-level control variables include the logarithm of the firm's preshock total assets, the firm's pre-shock ROA, and the firm's pre-shock leverage defined as the ratio of total debt to total assets. Additionally, we control for differences across a firm's lenders by including weighted averages of the lending banks' characteristics (i.e., pre-shock logarithm of assets, equity ratio, and ROA). ${ }^{48}$ Finally, standard errors in the firmlevel regressions are clustered by firms' main lender.

Total loans for the average firm declined by 7.8 percent over the crisis event (Table 1 , Panel C). The reduction on the firm level is larger than the reduction for the average loan (-3.8 percent; Table 1, Panel B), suggesting that larger loans are reduced relatively more over the crisis. ${ }^{49}$ We proceed by estimating Share (IRB loans), the effect of the firm-level share of IRB loans on aggregate loans outstanding for all 107,025 sample firms (column 1 of

\footnotetext{
${ }^{47}$ Aggregate loans also include loans from SA banks that are not taken into account for the definition of the variable Share (IRB-IRB loans). However, loans from IRB banks account for 85.4 percent of total loans for the average firm in the restricted sample. The remainder of 14.6 percent loans from SA banks simply adds noise and thus prevents us from finding a significant impact of the share of a firm's loans from IRB banks that are subject to IRB on changes in total firm loans.

${ }^{48}$ We use the amount that the firm borrows from a certain bank divided by the total loans of the firm prior to the crisis as a weight to calculate firm-level bank characteristics.

${ }^{49}$ See Section 5.2 for a detailed examination of this issue.
} 
Table 5). ${ }^{50}$ Firms receiving larger shares of IRB loans prior to the crisis experienced larger reductions in total borrowing following the recession. The coefficient remains highly significant and even increases in magnitude if we include variables that control for bank-level characteristics of a firm's lenders (column 2). Further, the effect is robust to the inclusion of firm-level control variables in the matched sample of 7,778 firms (columns 3 and 4). Importantly, the impact of the regulatory classification of a firm's loans on changes in the firm's aggregate loans is economically meaningful. For example, the coefficient in column 2 implies that a firm borrowing only IRB loans experienced a reduction in total loans that is on average 5.4 percent larger than the reduction for a firm that borrowed only SA loans. This magnitude increases to 10.7 percent in the matched sample where we control for firm level characteristics (column 4). Note that this magnitude is larger than the previously identified effect on the loan level (between 2.1 and 4.9 percent for Test 3). The reason for this is that large IRB loans are reduced the most following the crisis event (see Section 5.2 for details). A stronger reduction of larger IRB loans relative to SA loans results in a disproportionally large reduction of a firm's total loans if these loans are mostly classified as IRB.

To address potential differences in loan demand by firms that borrow from SA and IRB institutions, we restrict the sample to firms that have both SA and IRB loans from IRB banks. ${ }^{51}$ Reducing the sample in this way allows us to mitigate concerns regarding firm demand, since the classification of each loan depends on the bank-specific implementation plan as outlined in Section 2. Estimating Equation (3), we identify a significant impact of the share of a firm's loans from IRB banks that are subject to IRB on changes in firms' aggregate lending (Table 5, column 5). Again, the result is robust to the inclusion of weighted banklevel characteristics as well as firm-level characteristics in a matched sample (columns 6 to 8). In order to assess the economic magnitude of the coefficient we compare the firms at the $25^{\text {th }}$ and the $75^{\text {th }}$ percentile of the distribution for Share (IRB-IRB loans).$^{52}$ Based on the coefficient in column 6 , the firm that has relatively more IRB loans experiences a reduction

\footnotetext{
${ }^{50}$ This sample includes single-relationship firms as well as firms that have only SA loans or only IRB loans. For these firms, Share (IRB loans) is equal to zero or 1, respectively.

${ }^{51}$ Note that these are precisely the 7,159 firms that we use for identification in Test 3 (Section 4.1).

${ }^{52}$ The firm at the $25^{\text {th }}$ percentile has 42.6 percent IRB loans while the firm at the $75^{\text {th }}$ percentile has 81.7 percent IRB loans. The variable takes values between but excluding zero and one as we require that firms in this test have both SA loans and IRB loans from IRB banks.
} 
in total loans that is 4.5 percent larger than the reduction for the firm that has relatively more SA loans. It is worth noting that this result provides strong evidence for a causal effect of the regulatory classification of loans within IRB banks on aggregate firm loans following the crisis. While we consider only firms that borrow from different IRB banks in this test, we can identify a significant difference in aggregate firm borrowing that depends on how many of the firm's loans had already been transferred into IRB portfolios before the crisis event. This suggest that firms are unable to compensate for the reduction in IRB lending by switching to SA loans.

Finally, we investigate whether the regulatory classification of loans had an impact only on lending quantities or also on the price of lending. Since the documented increase in risk-weighted assets induced an increase of the capital charges for a given euro lent out, banks might also react by increasing the interest rate charged on IRB loans. While we cannot do this analysis on the loan level (since the German credit register does not report interest rates), we can link changes in the ratio of aggregate interest expense to loans from firms' balance sheets and income statements to their share of IRB loans before the crisis. Regression results are presented in columns 9 to 12 of Table 5. Column 9 shows that firms obtaining a larger share of IRB loans experience a greater increase in capital cost over the crisis. This effect, however, vanishes once we include (weighted) bank-level controls in column 10. In columns 11 and 12 we reduce the sample to firms that have both SA and IRB loans from IRB banks in order to account for potential differences in firm demand (see above). The coefficient for the IRB variable in the reduced sample, Share (IRB-IRB loans) , is insignificant in both regressions. Overall, we find only weak evidence that firms that obtain more IRB loans experience greater increases in capital costs over the crisis. Our results suggest that banks mostly reacted to the crisis event by adjusting the amounts of IRB loans outstanding in order to deleverage and fulfill regulatory requirements. 


\section{Further evidence: Impact of bank, loan, and firm char- acteristics on risk-specific capital charges and lending}

In Section 4.1 we showed that after the crisis shock banks reduced lending on IRB loans more than on SA loans. We argued that the underlying cause of this finding is that IRB loans require banks to increase their regulatory capital if PDs increase during a recession, whereas changes in the PD of SA loans have no effect on banks' regulatory capital requirements. Thus, we expect a stronger reaction to the crisis event (a) by banks with a low capital ratio before the recession; (b) for large IRB loans that have a substantial impact on capital charges when their PD deteriorates; and (c) for loans whose PD increases relatively more than others. In this section we present evidence for these three relationships.

\subsection{The lending reaction of IRB banks: The role of bank equity}

Hellwig (2010) argues that banks reduced buffers over minimum capital requirements to a bare minimum in an attempt to "economize on equity" prior to the crisis and that there was only limited scope for raising additional equity during the crisis. Thus, we would expect that banks that have lower capital ratios and are hence closer to the regulatory minimum will react more when capital requirements increase because of the crisis. We test this by creating a dummy variable that separates the IRB banks into those with a lower than median and those with a higher than median pre-shock equity ratio and estimate the following equation:

$$
\begin{aligned}
\Delta \log (\text { loans })_{i j} & =\beta_{1} \times{\text { Share } \mathrm{IRB}_{j}+\beta_{2} \times \mathrm{D}(\text { low equity })_{j}} \\
& +\beta_{3} \times \text { Share } \mathrm{IRB}_{j} \times \mathrm{D}(\text { low equity })_{j}+X_{j}^{\prime} \gamma+\varepsilon_{i j}
\end{aligned}
$$

In an alternative specification we include an interaction between banks' initial equity ratio and the variable Share IRB instead of the interaction with the dummy variable. In principle, it would be possible to include firm fixed effects in this equation to control for firm-specific

credit demand shocks as before. However, such a specification requires that each firm has 
at least four banking relationships in order to identify the coefficients. ${ }^{53}$ As the results from OLS and fixed effects regressions in Section 4.1 are very similar, we estimate Equation (4) with OLS.

Results are reported in Table 6 . The significantly negative coefficient for the interaction term in column 1 indicates that the effect of the regulatory approach is more pronounced for those IRB banks that had below median capital ratios prior to the crisis. Similarly, the positive coefficient for the interaction in column 2 shows that the negative effect of a higher share of IRB loans within the bank is mitigated by a higher pre-shock capitalization of the bank. This is consistent with our argument since banks with a high share of IRB loans and low capitalization are likely to experience larger increases in risk-weighted capital requirements and to react more strongly. Again, Test 2 and Test 3 show that this result is driven by the regulatory approach. While we do not find significant differences across banks in the sample of SA loans (columns 3 and 4), columns 5 and 6 show that among IRB banks the IRB loans from banks with relatively little equity are reduced the most over the crisis. The higher the initial capitalization of the bank, the less pronounced the relatively stronger reduction of IRB loans as compared to SA loans.

\subsection{The lending reaction of IRB banks: the role of loan size}

Next, we investigate whether the size of a loan has an influence on how it is affected during the crisis. For example, increases in risk weights for larger loans result in larger increases in required capital and hence banks are likely to respond more. For this purpose we calculate the bank's exposure to each loan by dividing the loan amount prior to the crisis by the bank's pre-shock total assets. An identical increase in risk weights would translate into a larger increase in required capital for loans to which the bank has a higher exposure. The same argument is true if we take the absolute size of the loan instead of the relative exposure

\footnotetext{
${ }^{53}$ For example, if the firm had only two loans, one from an IRB bank with low equity according to the dummy variable, and one SA bank with high equity, it would be impossible to say whether a potential difference in the change in lending of these banks was due to the regulatory approach or the capitalization of the banks. In order to clearly identify the effects, one would require the firm to have at least one loan from an IRB bank with low capital, one loan from an IRB bank with high capital, one loan from an SA bank with low capital and one loan from an SA bank with high capital.
} 
of the bank as a criterion. We then generate two dummy variables taking the value 1 if the exposure of the bank to a certain loan is larger than the median of our sample or if the loan is larger than the median loan in our sample, and zero otherwise.

We replace the equity variables in Equation (4) with the exposure and loan size dummies and show the results in Table 7. Column 1 shows that banks reduced loans relatively more over the crisis when they had a large exposure prior to the crisis, and that this is particularly true for banks with a high share of IRB loans that are vulnerable to increases in risk weights. The same result is obtained if we use loan size instead of relative exposure as shown in column 2: banks with higher shares of IRB loans reduce larger loans relatively more. Also, columns 3 and 4 show that among SA loans relatively larger loans are reduced relatively more. However, as before there is no significant difference between banks with different shares of IRB loans. Finally, columns 5 and 6 report results for Test 3. Among the sample of loans from IRB banks, loans to which the bank has a higher exposure are reduced relatively more, and this is especially true of IRB loans for which increases in risk weights translate into higher capital requirements for the bank.

\subsection{The lending reaction of IRB banks: The role of firm risk}

In this section we investigate the influence of firm risk on bank lending. So far we have shown that firms' PDs increase during a recession and therefore capital requirements increase for IRB loan portfolios. For the empirical analysis we assumed that increased PDs affect all IRB loans uniformly. However, a recession hits firms heterogeneously. The capital requirements would increase most for those firms whose PD increases the most. Relating changes in the PD to changes in lending is, however, problematic. A bank's lending decision has a direct impact on firms' leverage, and this again is a key determinant of a firm's PD. Therefore we need to find a firm characteristic that is likely to predict future changes in PD but is not directly affected by the banks' lending decision.

Our measure of a firm's likelihood of experiencing an increase in its PD is its preshock profitability, measured by its ROA in $2007 / 2008$. Current profitability is an important 
predictor of the firm's future PD, and it will be observed by the bank's analysts. We are able to obtain data on firm ROA from a matched firm sample with a total of 17,332 loans to 4,906 firms that borrow from at least two banks with a different share of IRB loans.

In Panel A of Table 8 we start with estimates of Equation (1) for the matched firm sample, which comprises about 20 percent of the original sample. The coefficient for the IRB variable is -0.045 , which is very close to the estimate with the full sample (Table 3 , column 2), indicating that our matched subsample is representative. Firm fixed effects are included and absorb firm-specific shocks to credit demand as before. We are able to include firm fixed effects because we are making comparisons across firms and not across banks or across loans. We are therefore able to split our sample into firms of different riskiness. We divide the sample into firms with a lower than median ROA and firms with a higher than median ROA and run the same regression on each subsample. As expected, the coefficient for the IRB variable is smaller for firms that are relatively less profitable prior to the crisis (column 2). It is larger and insignificant for the more profitable firms, as shown in column 3. Similar results are obtained if we use the loan-level instead of the bank-level IRB variable. ${ }^{54}$ Within the same firm, IRB loans are reduced more than SA loans, especially if the firm has a relatively low ROA prior to the crisis.

In Panel B of Table 8 we split the sample according to firms that experienced a negative change and those that experienced a positive change in PD during the crisis. As discussed above, this test is likely to suffer from endogeneity bias. Nevertheless, to demonstrate the plausibility of our categorization by pre-crisis ROA in Panel A, we also show results based on the actual change in PD. Since banks do not report PDs together with SA loans, we need to generate model-based PDs. We therefore use a credit risk model developed by Förstemann (2011) that applies firm balance sheet information in order to calculate firmspecific PDs. ${ }^{55}$ As in the ROA regressions, we split the sample into firms where the PD

\footnotetext{
${ }^{54}$ Unfortunately, there are not enough firms in the matched sample that have at least one SA loan and one IRB loan from an IRB bank, which would be the pre-condition for Test 3. Similarly, there are not enough firms that have SA loans from both SA banks and IRB banks in the matched sample. To circumvent this problem columns 4 to 6 also include SA loans from SA banks and test whether the regulatory approach used for a certain loan has an impact on how the loan is affected by the crisis. Bank-level control variables are included in all regressions to account for systematic differences across banks.

${ }^{55}$ See Section 2.2 for details.
} 
increased over the crisis and firms where it decreased.

The results in Panel B are very similar to the results in Panel A: while banks with a higher share of IRB loans reduce lending to the same firm relatively more, this result seems to be driven by firms for which the PD increased over the crisis (column 2). The coefficient for firms with a decrease in PD is smaller in absolute terms and insignificant. A similar result is obtained for the loan-level IRB variable in columns 4 to 6 .

In summary, our results show that the effect of a reduction of lending by IRB banks or a reduction of IRB loans is especially pronounced for IRB institutions with a low level of equity. Furthermore, IRB banks tend to ration loans that are large and also loans to firms that are likely to experience an increase in PD. These findings provide further support for our claim and underline the transmission channel through which the introduction of internal ratings affects banks' loan supply.

\section{Conclusion and discussion}

In this paper we overcome complex identification issues and estimate how capital regulation based on individual asset risk affects bank lending. We employ the gradual introduction of Basel II in Germany as a laboratory and use the recession shock following the collapse of Lehman Brothers in September 2008 as an event that increased credit risk in the German market for corporate loans. Our main finding is that the pro-cyclicality of capital charges based on individual asset risk has a significant effect on the lending behavior of banks as well as a considerable effect on firms' aggregate ability to borrow. For a given firm, loans by different IRB banks are reduced by 3.7 percent more when internal ratings (IRB) instead of fixed risk weights (SA) are used to determine capital charges. Since banks tend to ration large IRB loan exposures relatively more, the effect is even stronger on the aggregate firm level: firms that had only IRB loans prior to the crisis experienced a reduction in total loans that was 5 to 10 percent larger than the reduction for firms that had only SA loans.

Our findings have important policy implications for the design of bank capital regula- 
tion. The new Basel III framework includes measures that are meant to address the problem of pro-cyclicality. Most important, Basel III introduces a countercyclical capital buffer that requires banks to build up additional capital reserves in times of excessive credit growth which can be used to satisfy capital requirements when economic conditions deteriorate. Our findings could be interpreted as justification for such a measure. However, countercyclical capital buffers reduce pro-cyclicality only if the supervisor has sufficient foresight about future economic conditions. ${ }^{56}$ By definition, the regulator cannot anticipate unexpected shocks to credit risk (e.g., shocks that originate abroad such as the one analyzed in this paper) and therefore cannot always pre-empt such shocks by setting buffer rates accordingly. Furthermore, Basel III introduces capital conservation buffers. While these buffers are not per se anti-cyclical, they are meant to address the problem of pro-cyclicality by reducing the pressure on banks to deleverage when economic conditions deteriorate. However, they also do not solve the basic problem of pro-cyclical capital requirements, as their release has severe consequences for banks, and markets might not accept lower capital ratios when economic conditions deteriorate. ${ }^{57}$ One solution to the problem of pro-cyclicality would be the introduction of a simple leverage ratio. While this would solve the problem of pro-cyclicality, the link between capital charges and actual asset risk would vanish. ${ }^{58}$

Asset-risk-specific capital regulation, the most important feature of both Basel II and Basel III, has an inherent problem of pro-cyclicality. Our results show for the first time that pro-cyclical capital charges under the model-based approach affect both bank lending and firms' access to funds. Moreover, in our view the measures introduced in the Basel III framework are insufficient to fully address this problem. To make a final judgment regarding the efficiency of risk-based capital requirements requires further research on the costs and benefits of this regulatory approach.

\footnotetext{
${ }^{56}$ In particular, the buffer works only if the credit-to-GDP ratio (or any other measure the supervisor might use in order to define "excessive credit growth") is a sufficient statistic for future economic conditions.

${ }^{57}$ Capital conservation buffers are buffers on top of the minimum capital requirements. Once the bank's capital ratio is below the sum of the minimum requirement and the capital conservation buffer, it faces restrictions on dividend payments. These restrictions remain in place until the buffer is replenished.

${ }^{58}$ In Europe, a levererage ratio will tentatively be introduced in 2017 . However, its currently discussed level, 3 percent of total (unweighted) assets, is rather low, so that it would serve only as a backstop against excessive leverage. Risk-based capital requirements would remain the binding ones in most cases.
} 


\section{References}

Acharya, V. (2009). A theory of systemic risk and design of prudential bank regulation. Journal of Financial Stability, 5(3):224-255.

Acharya, V., Mehran, H., Schuermann, T., and Thakor, A. (2012). Robust capital regulation. Current Issues in Economics and Finance, Federal Reserve Bank of New York.

Admati, A. R., DeMarzo, P. M., Hellwig, M. F., and Pfleiderer, P. (2012). Debt overhang and capital regulation. Preprints of the Max Planck Institute for Research on Collective Goods Bonn 2012/5.

Aiyar, S., Calomiris, C. W., and Wiedalek, T. (2012). Does macro-pru leak? Evidence from a UK policy experiment. NBER Working Paper Series.

Andersen, H. (2011). Procyclical implications of Basel II: Can the cyclicality of capital requirements be contained? Journal of Financial Stability, 7:138-154.

Ayuso, J., Pérez, D., and Saurina, J. (2004). Are capital buffers pro-cyclical? Evidence from Spanish panel data. Journal of Financial Intermediation, 13(2):249-264.

Basel Committee on Banking Supervision (1988). International convergence of capital measurement and capital standards. Bank for International Settlements, Basel, Switzerland.

Basel Committee on Banking Supervision (1999). Capital requirements and bank behaviour: The impact of the Basle Accord. Bank for International Settlements, Basel, Switzerland.

Basel Committee on Banking Supervision (2006). International convergence of capital measurement and capital standards - A revised framework. Bank for International Settlements, Basel, Switzerland.

Berger, A. N. and Udell, G. F. (1994). Did risk-based capital allocate bank credit and cause a "credit crunch" in the United States? Journal of Money, Credit and Banking, 26(3):585628. 
Bernanke, B. S. (1983). Nonmonetary effects of the financial crisis in the propagation of the great depression. American Economic Review, 73(3):257-276.

Bernanke, B. S., Lown, C. S., and Friedman, B. M. (1991). The credit crunch. Brookings Papers on Economic Activity, 1991(2):205-247.

Bertrand, M., Duflo, E., and Mullainathan, S. (2004). How much should we trust differences-in-differences estimates? Quarterly Journal of Economics, 119(1):249-275.

Bhattacharya, S., Boot, A. W., and Thakor, A. V. (1998). The economics of bank regulation. Journal of Money, Credit and Banking, 30(4):745-770.

Blum, J. and Hellwig, M. (1995). The macroeconomic implications of capital adequacy requirements for banks. European Economic Review, 39(3-4):739-749.

Borio, C., Furfine, C., and Lowe, P. (2001). Procyclicality of the financial system and financial stability: issues and policy options. BIS Working Paper.

Brunnermeier, M. K. (2009). Deciphering the liquidity and credit crunch 2007-2008. Journal of Economic Perspectives, 23(1):77-100.

Brunnermeier, M. K., Goodhart, C. A. E., Persaud, A., Crockett, A., and Shin, H. (2009). The fundamental principles of financial regulation. Centre for Economic Policy Research, London.

Bundesbank (2005). Approval for banks to use internal ratings based (IRB) approaches to calculate regulatory capital requirements in Germany. Monthly Report June, pages 1-14.

Bundesbank (2006). Die Umsetzung der neuen Eigenkapitalregelungen für Banken in deutsches Recht. Monatsbericht Dezember, pages 69-91.

Carling, K., Jacobson, T., Lindé, J., and Roszbach, K. (2002). Capital charges under Basel II: Corporate credit risk modelling and the macro economy. Sveriges Riksbank Working Paper Series.

Catarineu-Rabell, E., Jackson, P., and Tsomocos, D. P. (2003). Procyclicality and the new Basel accord - Banks choice of loan rating system. Bank of England Working Paper. 
Corcóstegui, C., González-Mosquera, L., Marcelo, A., and Trucharte, C. (2002). Analysis of procyclical effects on capital requirements derived from a rating system. Banco de España Working Paper Series.

Daníelsson, J., Embrechts, P., Goodhart, C., Keating, C., Muennich, F., Renault, O., and Shin, H. S. (2001). An academic response to Basel II. LSE Financial Markets Group, Special Paper No. 130.

Diamond, D. W. and Rajan, R. G. (2000). A theory of bank capital. Journal of Finance, 55(6):2431-2465.

Diamond, D. W. and Rajan, R. G. (2001). Liquidity risk, liquidity creation, and financial fragility: A theory of banking. Journal of Political Economy, 109(2):287-327.

Drumond, I. (2009). Bank capital requirements, business cycle fluctuations and the Basel accords: A synthesis. Journal of Economic Surveys, 23(3):798-830.

Financial Stability Institute (2010). Survey on the Implementation of the New Capital Adequacy Framework. Bank for International Settlements, Basel, Switzerland.

Förstemann, T. (2011). Improvements in rating models for the German corporate sector. Bundesbank Discussion Paper.

Francis, W. and Osborne, M. (2009). Bank regulation, capital and credit supply: Measuring the impact of prudential standards. FSA Occassional Papers in Financial Regulation.

Galati, G. and Moessner, R. (2012). Macroprudential policy - A literature review. Journal of Economic Surveys, online early view.

Gambacorta, L. and Mistrulli, P. E. (2004). Does bank capital affect lending behavior? Journal of Financial Intermediation, 13(4):436-457.

Goodhart, C., Hofman, B., and Segoviano, M. (2004). Bank regulation and macroeconomic fluctuations. Oxford Review of Economic Policy, 20(4):591-615.

Gordy, M. B. and Howells, B. (2006). Procyclicality in Basel II: Can we treat the disease without killing the patient? Journal of Financial Intermediation, 15(3):395-417. 
Halvorsen, R. and Palmquist, R. (1980). The interpretation of dummy variables in semilogarithmic equations. American Economic Review, 70(3):474-475.

Hanson, S. G., Kashyap, A. K., and Stein, J. C. (2011). A macroprudential approach to financial regulation. Journal of Economic Perspectives, 25(1):3-28.

Heid, F. (2007). The cyclical effects of the Basel II capital requirements. Journal of Banking and Finance, 31(12):3885-3900.

Hellwig, M. (2009). Systemic risk in the financial sector: An analysis of the subprimemortgage financial crisis. De Economist, 157(2):129-207.

Hellwig, M. (2010). Capital regulation after the crisis: Business as usual? CESifo DICE Report, 8(2):40-46.

Ivashina, V. and Scharfstein, D. (2010). Bank lending during the financial crisis of 2008. Journal of Financial Economics, 97(3):319-338.

Iyer, R., Da-Rocha-Lopes, S., Peydró, J.-L., and Schoar, A. (2013). Interbank liquidity crunch and the firm credit crunch: Evidence from the 2007-2009 crisis. Review of Financial Studies, forthcoming.

Jiménez, G., Ongena, S., Peydró, J.-L., and Saurina, J. (2013a). Hazardous times for monetary policy: What do twenty-three million bank loans say about the effects of monetary policy on credit risk-taking? Econometrica, forthcoming.

Jiménez, G., Ongena, S., Peydró, J.-L., and Saurina, J. (2013b). Macroprudential policy, countercyclical bank capital buffers and credit supply: Evidence from the Spanish dynamic provisioning experiments. European Banking Center Discussion Paper.

Jokipii, T. and Milne, A. (2008). The cyclical behaviour of European bank capital buffers. Journal of Banking and Finance, 32(8):1440-1451.

Kahle, K. M. and Stulz, R. M. (2013). Access to capital, investment, and the financial crisis. Journal of Financial Economics, forthcoming. 
Kashyap, A., Rajan, R., and Stein, J. (2008). Rethinking capital regulation. In Federal Reserve Bank of Kansas City Symposium at Jackson Hole, pages 431-471.

Kashyap, A. K. and Stein, J. C. (2000). What do a million observations on banks say about the transmission of monetary policy? American Economic Review, 90(3):407-428.

Kashyap, A. K. and Stein, J. C. (2004). Cyclical implications of the Basel II capital standards. Federal Reserve Bank of Chicago: Economic Perspectives, (1):18-31.

Khwaja, A. I. and Mian, A. (2008). Tracing the impact of bank liquidity shocks: Evidence from an emerging market. American Economic Review, 98(4):1413-1442.

Kim, D. and Santomero, A. M. (1988). Risk in banking and capital regulation. Journal of Finance, 43(5):1219-1233.

Koehn, M. and Santomero, A. M. (1980). Regulation of bank capital and portfolio risk. Journal of Finance, 35(5):1235-1244.

Lindquist, K.-G. (2004). Banks buffer capital: How important is risk? Journal of International Money and Finance, 23(3):493-513.

Lowe, P. (2002). Credit risk measurement and procyclicality. BIS Working Paper.

Lowe, P. and Segoviano, M. A. (2002). Internal ratings, the business cycle and capital requirements: Some evidence from an emerging market economy. BIS Working Paper.

Morrison, A. D. and White, L. (2005). Crises and capital requirements in banking. American Economic Review, 95(5):1548-1572.

Paravisini, D., Rappoport, V., Schnabl, P., and Wolfenzon, D. (2013). Dissecting the effect of credit supply on trade: Evidence from matched credit-export data. Working Paper.

Peek, J. and Rosengren, E. (1995a). Bank regulation and the credit crunch. Journal of Money, Credit and Banking, 27(3):625-638.

Peek, J. and Rosengren, E. (1995b). The capital crunch: Neither a borrower nor a lender be. Journal of Banking and Finance, 1(1):3-11. 
Peek, J. and Rosengren, E. S. (1997). The international transmission of financial shocks: The case of Japan. American Economic Review, 87(4):495-505.

Peek, J. and Rosengren, E. S. (2000). Collateral damage: Effects of the Japanese bank crisis on real activity in the United States. American Economic Review, 90(1):30-45.

Peltzman, S. (1970). Capital investment in commercial banking and its relationship to portfolio regulation. Journal of Political Economy, 78(1):1-26.

Puri, M., Rocholl, J., and Steffen, S. (2011). Global retail lending in the aftermath of the U.S. financial crisis: Distinguishing between supply and demand effects. Journal of Financial Economics, 100(3):556-578.

Repullo, R., Saurina, J., and Trucharte, C. (2010). Mitigating the pro-cyclicality of Basel II. Economic Policy, 25(64):659-702.

Repullo, R. and Suarez, J. (2012). The procyclical effects of bank capital regulation. Review of Financial Studies, 26(2):452-490.

Rochet, J.-C. (2008). Procyclicality of financial systems: Is there a need to modify current accounting and regulatory rules? Banque de France Financial Stability Review, (12):9599.

Saurina, J. and Trucharte, C. (2007). An assessment of Basel II procyclicality in mortgage portfolios. Banco De España Working Paper.

Solvabilitätsverordnung (2006). Verordnung über die angemessene Eigenmittelausstattung von Instituten, Institutsgruppen und Finanzholding-Gruppen. Bundesministerium für Finanzen, Berlin, Germany.

Thakor, A. V. (1996). Capital requirements, monetary policy, and aggregate bank lending: Theory and empirical evidence. Journal of Finance, 51(1):279-324. 


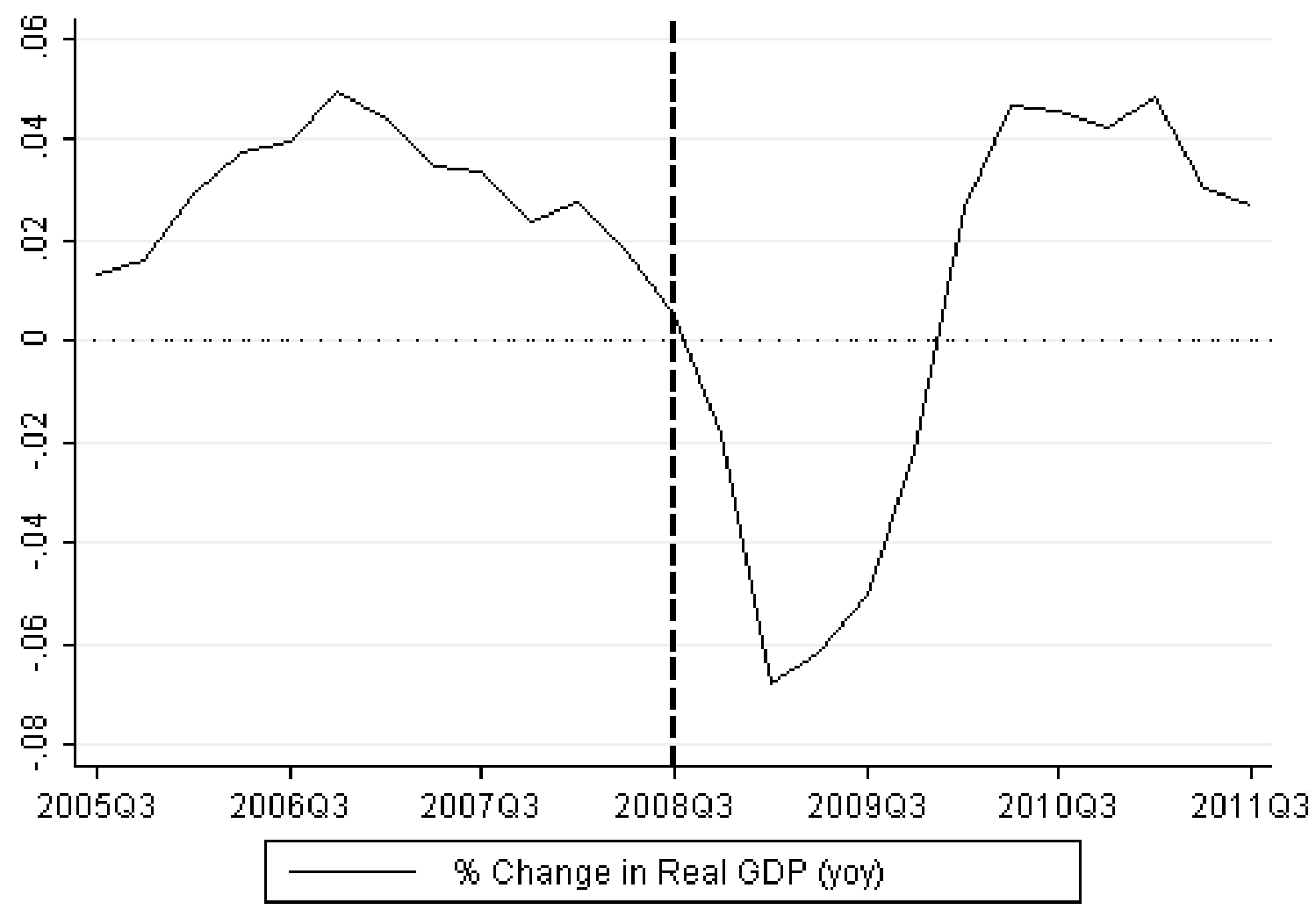

Figure 1: The crisis shock and the German economy.

This figure shows the year-over-year growth rate of GDP in Germany. The dashed vertical line indicates the crisis event in September 2008. (Source: Data from the German Federal Statistical Office.) 


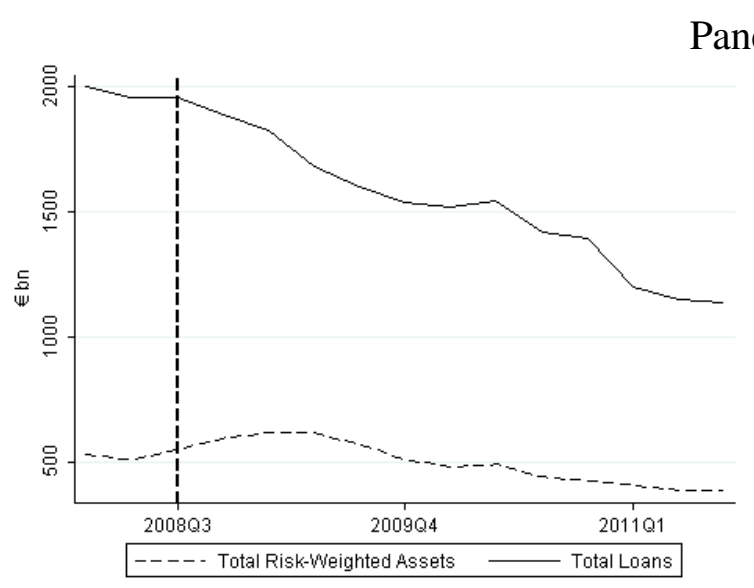

Panel A

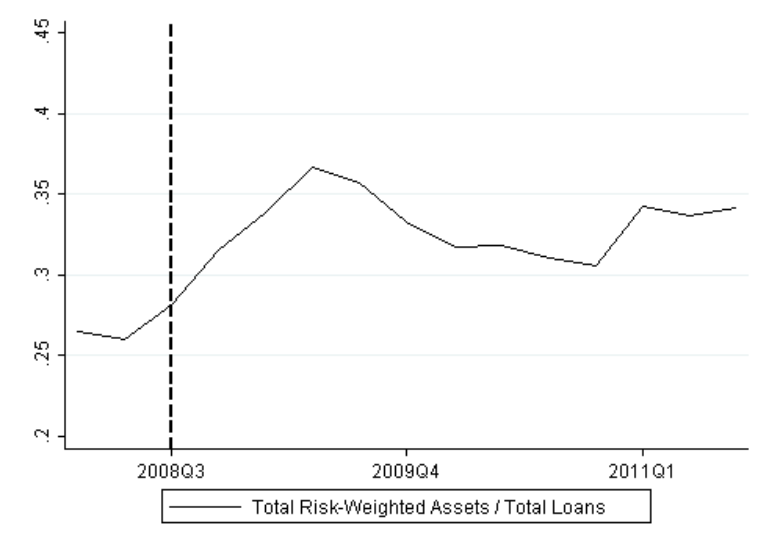

Panel B
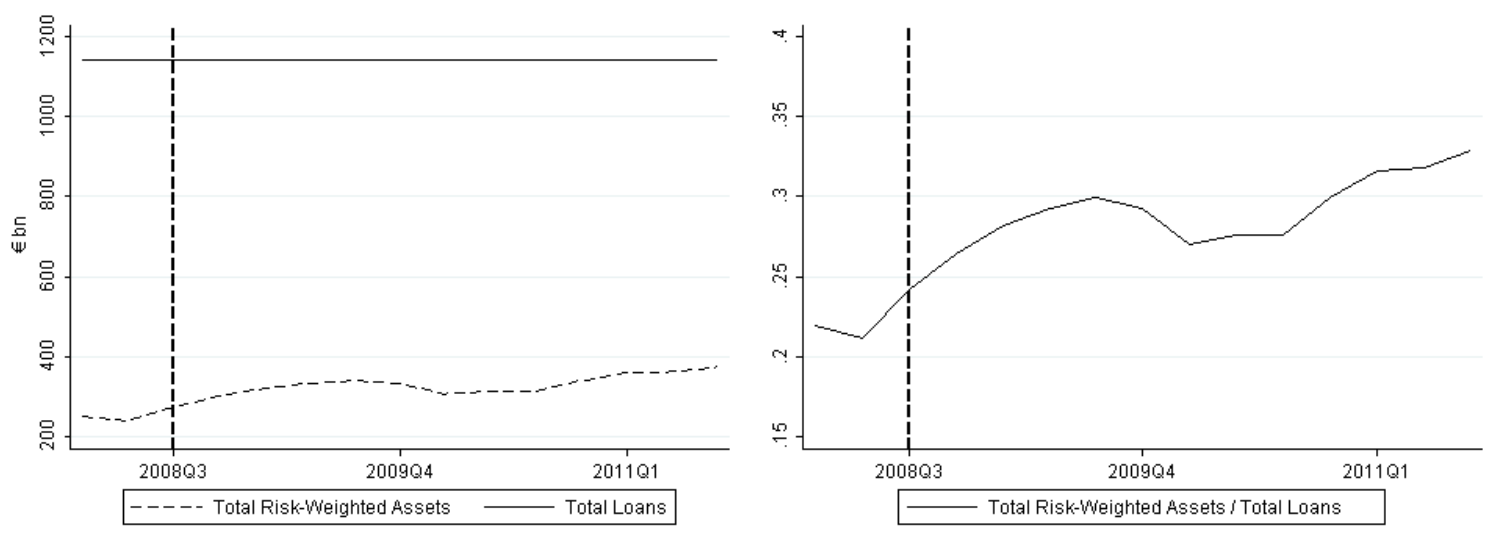

Figure 2: Total risk-weighted loans and total loans.

Panel A shows how total risk-weighted loans and total loans evolve over time. The series include only those lending relationships that existed prior to the crisis event; i.e., we do not include lending relationships that were originated after the crisis shock. The left graph shows the development of total loans and total risk-weighted assets for these loans. The right graph depicts the ratio of total risk-weighted assets to total loans. Panel B shows how total risk-weighted assets and total loans would have evolved over time for a constant portfolio of loans. We include all loans that exist throughout the entire sample period and calculate the risk weight for each loan at each point in time. We then calculate hypothetical risk-weighted loans in a given period by multiplying the loan amount of 2008Q3 with the risk weight for the respective period. In a final step we aggregate the calculated risk weighted loans in each period and divide it by the (constant) amount of total loans in 2008Q3 to obtain the ratio of total risk-weighted loans to total loans for a constant portfolio of loans. The left graph shows the aggregate series. The right graph shows the ratio between the two. 


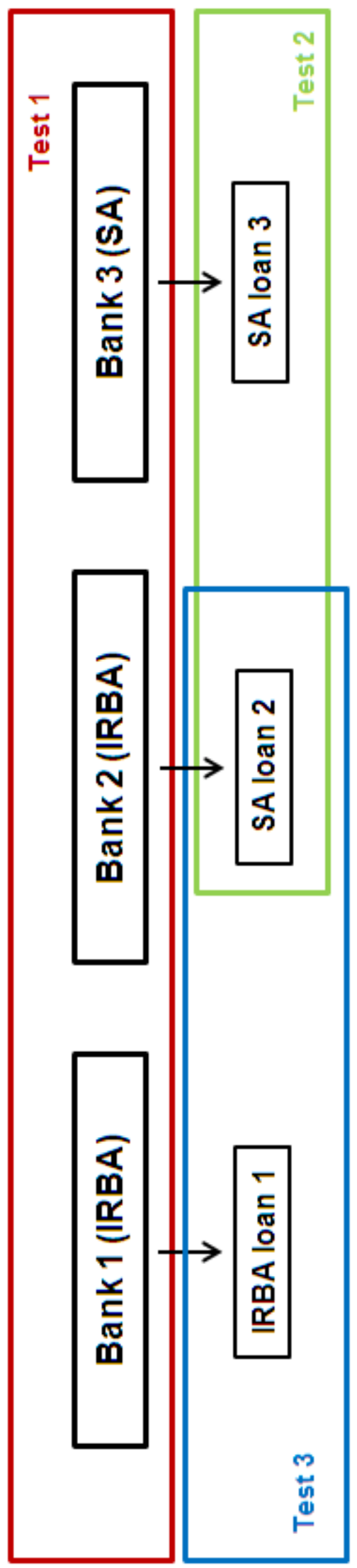

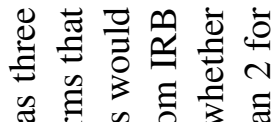

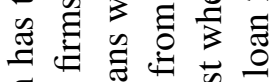

छ $ᄋ$ 원

ส

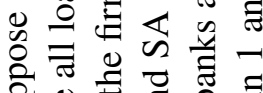

䒕

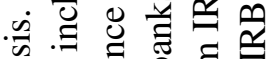

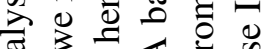

元

ซ్రై

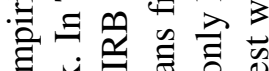
ฮี่ \&

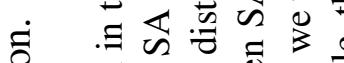

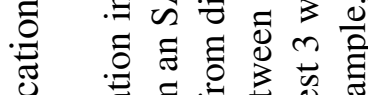

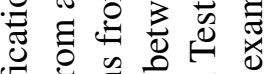

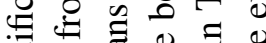
드응 응월

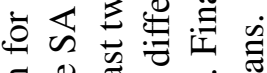
ฮ ฮั ซ

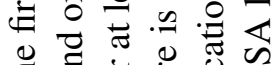

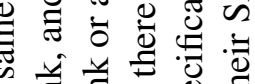
क ปี ปี

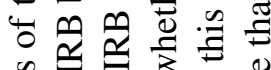
茦吉 气 $\frac{\pi}{0} \Xi \geqq \Xi ㅇ$ 층 흐용

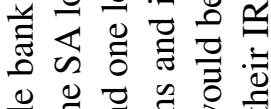

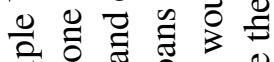

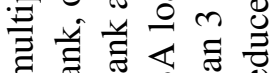

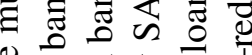
总出交芯

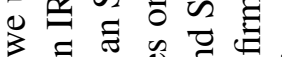

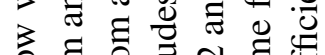

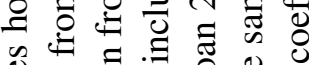
ขै สี 응 퓨워

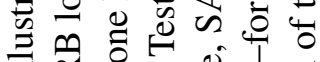
$\equiv$ 正

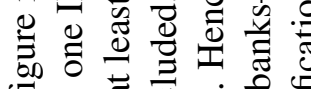

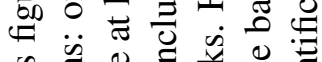

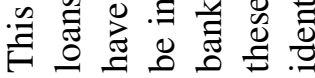


Table 1: Summary statistics

\begin{tabular}{|c|c|c|c|c|c|}
\hline \multicolumn{6}{|l|}{ Panel A: Bank-level variables } \\
\hline & \multicolumn{2}{|c|}{ 1,784 SA banks } & & \multicolumn{2}{|c|}{41 IRB banks } \\
\hline & Mean & S. D. & & Mean & S. D. \\
\hline Share IRB & 0 & 0 & & 0.620 & 0.371 \\
\hline Total assets in $€ \mathrm{mn}$ (pre-event) & 1,080 & 2,580 & & 138,000 & 307,000 \\
\hline Bank equity ratio (pre-event) & 0.067 & 0.051 & & 0.046 & 0.029 \\
\hline Bank ROA (pre-event) & 0.006 & 0.012 & & 0.006 & 0.010 \\
\hline \multicolumn{6}{|l|}{ Bank Type } \\
\hline ... Commercial & $8.7 \%$ & - & & $58.5 \%$ & - \\
\hline ... State & $24.4 \%$ & - & & $31.7 \%$ & - \\
\hline ... Cooperative & $66.8 \%$ & - & & $9.8 \%$ & - \\
\hline \multicolumn{6}{|l|}{ Panel B: Loan-level variables } \\
\hline & Obs. & Mean & S.D. & & \\
\hline Loan size in $€ \mathrm{mn}$ (pre-event) & 182,966 & 16.1 & 38.4 & & \\
\hline $\mathrm{D}$ (IRB bank) & 182,966 & 0.495 & 0.500 & & \\
\hline D(IRB loan) & 182,966 & 0.336 & 0.472 & & \\
\hline Change in log lending & 182,966 & -0.038 & 0.456 & & \\
\hline PD (pre-event) & 64,880 & 0.041 & 0.160 & & \\
\hline Change in PD & 64,880 & 0.037 & 0.145 & & \\
\hline RWAs/loans (pre-event) & 53,278 & 0.437 & 0.448 & & \\
\hline Change in RWAs/loans & 53,278 & 0.067 & 0.461 & & \\
\hline \multicolumn{6}{|l|}{ Panel C: Firm-level variables } \\
\hline & Firms & Mean & S.D. & & \\
\hline Firm assets in $€ m n$ (pre-event) & 7,778 & 153.4 & 347.9 & & \\
\hline Firm ROA (pre-event) & 7,778 & 0.063 & 0.093 & & \\
\hline Firm leverage ratio (pre-event) & 7,778 & 0.133 & 0.141 & & \\
\hline Firm PD (pre-event) & 7,136 & 0.016 & 0.022 & & \\
\hline Total firm loans in $€ \mathrm{mn}$ (pre-event) & 107,025 & 22.7 & 67.5 & & \\
\hline Change in log of total firm loans & 107,025 & -0.078 & 0.399 & & \\
\hline Firm capital cost (pre-event) & 4,977 & 0.0829 & 0.0712 & & \\
\hline Change in firm capital cost & 4,977 & -0.0011 & 0.0201 & & \\
\hline \multicolumn{6}{|l|}{ Panel D: Identifying observations } \\
\hline & Test 1 & Test 2 & Test 3 & & \\
\hline Firms & 20,740 & 10,496 & 7,167 & & \\
\hline Observations & 93,370 & 49,492 & 27,620 & & \\
\hline a) ... of which from SA bank & 44,423 & 35,852 & & & \\
\hline ... of which from IRB bank & 48,947 & 13,640 & & & \\
\hline b) ... of which SA loans & & & 9,226 & & \\
\hline ... of which IRB loans & & & 18,394 & & \\
\hline
\end{tabular}

Panel A shows descriptive statistics for the groups of SA and IRB banks. An IRB bank is defined as a bank that uses the internal ratings-based approach for some loans during our sample period, whereas an SA bank is defined as a bank that uses the Basel II standard approach in all its lending relationships. Panel B shows summary statistics for all loans of commercial, state, and cooperative banks for which we are able to determine the regulatory approach used at the beginning of our sample period. Panel C shows summary statistics for the matched sample of 7,778 firms for which we are able to obtain firm balance sheet information. Moreover, it includes information on aggregate loans of the 107,025 firms in our sample. Panel D shows the number of identifying observations in our three main tests. Test 1 requires that the firm has at least one loan from an SA bank and at least one loan from an IRB bank or at least two loans from distinct IRB banks, a condition that holds for 20,740 distinct firms with 93,370 loans. Test 2 requires that the firm has an SA loan from both an SA bank and an IRB bank or from two distinct IRB banks. Test 3 requires that the firm has both an SA loan and an IRB loan from an IRB bank (see Section 3 for details). 
Table 2: Classification of IRB/SA loans in 2008Q1

\begin{tabular}{|c|c|c|c|c|c|}
\hline & \multicolumn{5}{|c|}{ "Dependent variable: D(IRB loan) } \\
\hline & (1) & (2) & (3) & (4) & $(5)$ \\
\hline Loan share & $\begin{array}{c}1.899 * * * \\
(0.474)\end{array}$ & & & & $\begin{array}{c}3.645^{* *} \\
(1.790)\end{array}$ \\
\hline Portfolio PD & & $\begin{array}{l}-1.194 \\
(2.671)\end{array}$ & & & $\begin{array}{l}-6.713 \\
(6.465)\end{array}$ \\
\hline Log loans (pre-event) & & & $\begin{array}{c}0.072 \\
(0.053)\end{array}$ & & $\begin{array}{c}0.048 \\
(0.038)\end{array}$ \\
\hline Log firm assets (pre-event) & & & & $\begin{array}{c}0.081 \\
(0.064)\end{array}$ & $\begin{array}{c}0.067 \\
(0.060)\end{array}$ \\
\hline Firm ROA (pre-event) & & & & $\begin{array}{c}0.631 \\
(0.409)\end{array}$ & $\begin{array}{c}0.607 \\
(0.403)\end{array}$ \\
\hline Firm Leverage (pre-event) & & & & $\begin{array}{r}-0.080 \\
(0.109)\end{array}$ & $\begin{array}{l}-0.080 \\
(0.089)\end{array}$ \\
\hline Firm PD (pre-event) & & & & $\begin{array}{c}0.485 \\
(1.929)\end{array}$ & $\begin{array}{c}0.758 \\
(1.908)\end{array}$ \\
\hline Bank dummies & YES & YES & YES & YES & YES \\
\hline Observations & 87,725 & 87,725 & 87,725 & 10,405 & 10,405 \\
\hline Pseudo R-squared & 0.343 & 0.340 & 0.343 & 0.573 & 0.575 \\
\hline
\end{tabular}

The table shows results for simple probit regressions. The dependent variable is equal to 1 if the loan from bank $j$ to firm $i$ is subject to IRB and equal to zero if the loan is subject to the standard approach. The regressions include only loans from IRB banks. Robust standard errors adjusted for clustering at the bank level are reported in parentheses. Note: * indicates statistical significance at the $10 \%$ level, ** at the $5 \%$ level and $* * *$ at the $1 \%$ level. 


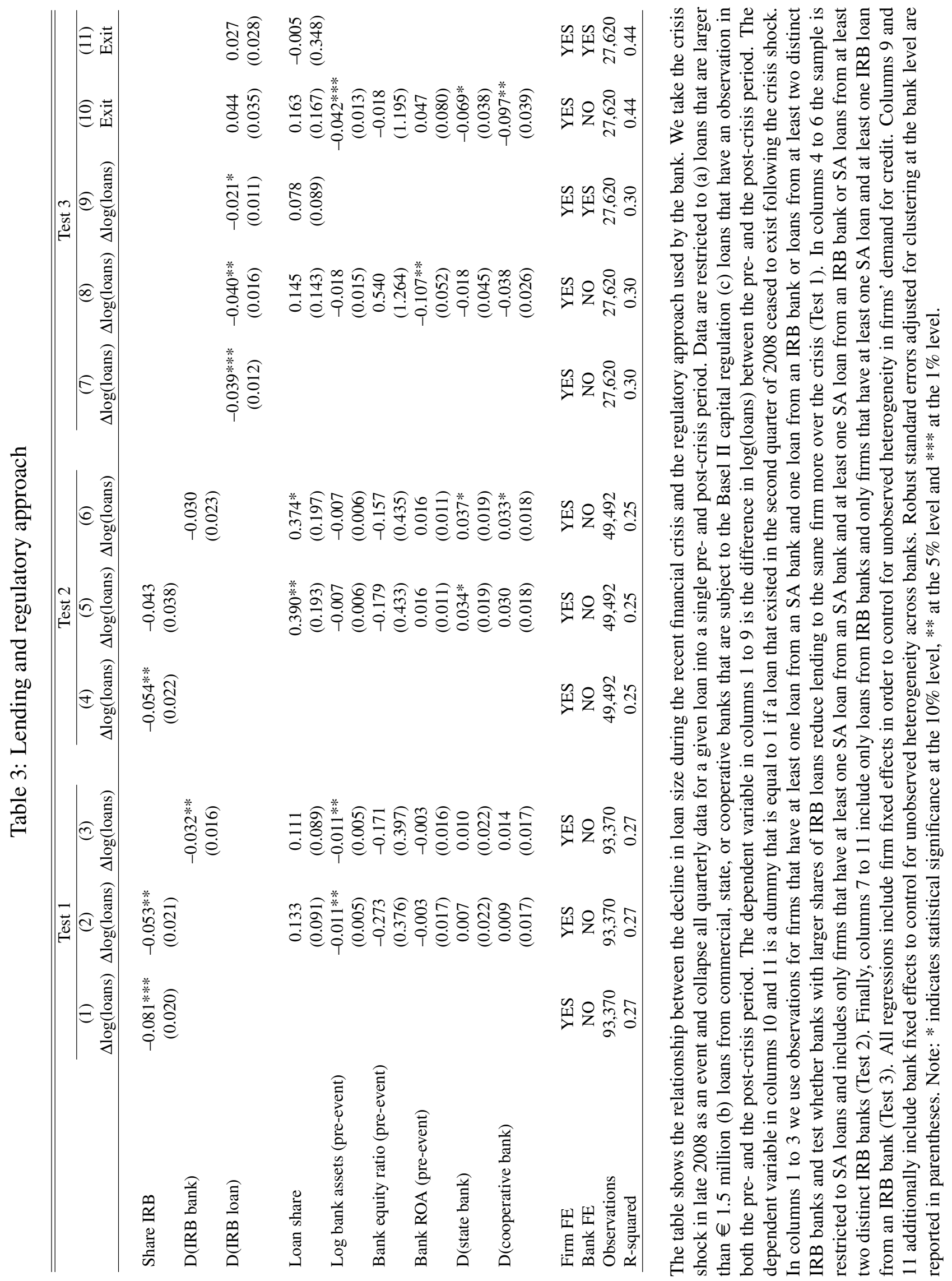









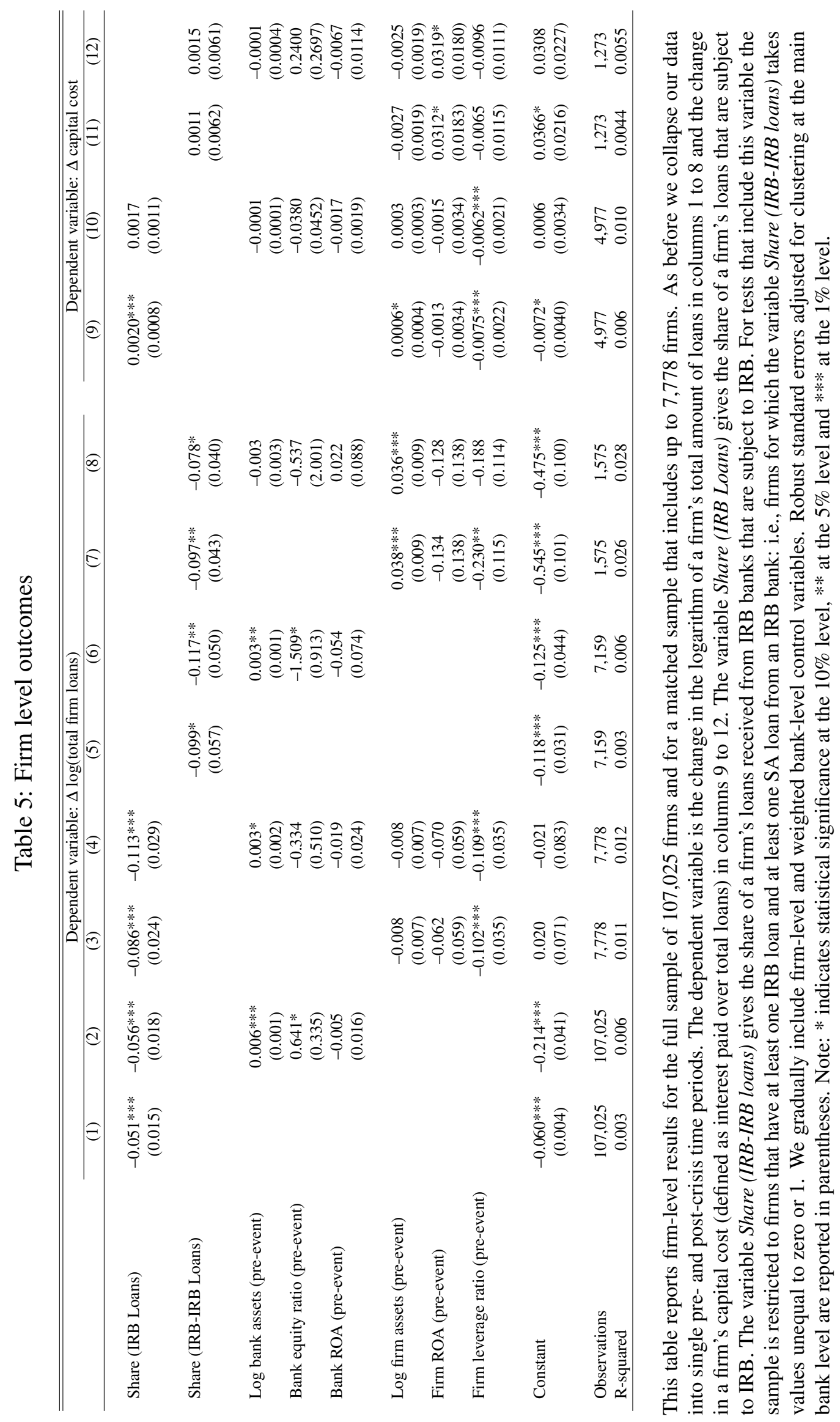


Table 6: Bank capitalization, regulatory approach, and lending

\begin{tabular}{|c|c|c|c|c|c|c|}
\hline & \multicolumn{6}{|c|}{ Dependent variable: $\Delta \log$ (loans) } \\
\hline & \multicolumn{2}{|c|}{ Test 1} & \multicolumn{2}{|c|}{ Test 2} & \multicolumn{2}{|c|}{ Test 3} \\
\hline & (1) & (2) & (3) & (4) & (5) & (6) \\
\hline Share IRB $\times$ Dummy(low equity) & $\begin{array}{c}-0.207 * * \\
(0.081)\end{array}$ & & $\begin{array}{l}-0.064 \\
(0.102)\end{array}$ & & & \\
\hline Share IRB $\times$ bank equity ratio (pre-event) & & $\begin{array}{l}1.897 * \\
(1.121)\end{array}$ & & $\begin{array}{l}-1.048 \\
(1.368)\end{array}$ & & \\
\hline D(IRB loan $) \times$ Dummy(low equity $)$ & & & & & $\begin{array}{c}-0.046^{* *} \\
(0.020)\end{array}$ & \\
\hline $\mathrm{D}(\mathrm{IRB}$ loan $) \times$ bank equity ratio (pre-event) & & & & & & $\begin{array}{l}2.117 * \\
(1.057)\end{array}$ \\
\hline Share IRB & $\begin{array}{l}-0.016 \\
(0.014)\end{array}$ & $\begin{array}{c}-0.104 * * \\
(0.045)\end{array}$ & $\begin{array}{l}-0.009 \\
(0.023)\end{array}$ & $\begin{array}{c}0.016 \\
(0.047)\end{array}$ & & \\
\hline D(IRB loan) & & & & & $\begin{array}{l}-0.017 \\
(0.012)\end{array}$ & $\begin{array}{c}-0.102 * * * \\
(0.030)\end{array}$ \\
\hline Constant & $\begin{array}{c}0.132 * * \\
(0.065)\end{array}$ & $\begin{array}{c}0.096 \\
(0.080)\end{array}$ & $\begin{array}{c}0.071 \\
(0.064)\end{array}$ & $\begin{array}{c}0.062 \\
(0.063)\end{array}$ & $\begin{array}{c}0.141 \\
(0.162)\end{array}$ & $\begin{array}{c}0.121 \\
(0.181)\end{array}$ \\
\hline Bank controls & YES & YES & YES & YES & YES & YES \\
\hline Observations & 182,966 & 182,966 & 121,549 & 121,549 & 90,500 & 90,500 \\
\hline R-squared & 0.006 & 0.005 & 0.002 & 0.002 & 0.004 & 0.003 \\
\hline
\end{tabular}

These regressions examine the impact of the regulatory approach on the change in lending for banks of differing levels of capitalization. As before, our quarterly data are collapsed into single pre- and post-crisis time periods and the dependent variable is the change in $\log (\operatorname{loans})$ for a bank-firm relationship. We include all loans in columns 1 and 2 (Test 1), only SA loans in columns 3 and 4 (Test 2), and only loans from IRB banks in columns 5 and 6 (Test 3). The Dummy(low equity) has the value 1 for banks with equity ratios below the median and zero otherwise. It is interacted with the share of IRB loans within the bank in columns 1 and 3 and with the IRB loan dummy in column 5. Alternatively, we include an interaction between the bank's initial equity ratio and the respective IRB variable in columns 2 , 4, and 6 . Bank control variables are the same as in previous tables. All variables that are included in interactions terms are also included on their own. Robust standard errors adjusted for clustering at the bank level are reported in parentheses. Note: * indicates statistical significance at the $10 \%$ level, $* *$ at the $5 \%$ level and $* * *$ at the $1 \%$ level. 
Table 7: Loan cross-section

\begin{tabular}{|c|c|c|c|c|c|c|}
\hline & \multicolumn{6}{|c|}{ Dependent variable: $\Delta \log ($ loans $)$} \\
\hline & \multicolumn{2}{|c|}{ Test 1} & \multicolumn{2}{|c|}{ Test 2} & \multicolumn{2}{|c|}{ Test 3} \\
\hline & (1) & (2) & (3) & (4) & (5) & (6) \\
\hline Share IRB $\times$ D(high exposure $)$ & $\begin{array}{c}-0.133 * * * \\
(0.039)\end{array}$ & & $\begin{array}{l}-0.045 \\
(0.044)\end{array}$ & & & \\
\hline Share IRB $\times \mathrm{D}($ large loan $)$ & & $\begin{array}{c}-0.180 * * * \\
(0.061)\end{array}$ & & $\begin{array}{l}-0.050 \\
(0.044)\end{array}$ & & \\
\hline $\mathrm{D}($ IRB loan $) \times \mathrm{D}($ high exposure $)$ & & & & & $\begin{array}{c}-0.115 * * \\
(0.045)\end{array}$ & \\
\hline $\mathrm{D}($ IRB loan $) \times \mathrm{D}$ (large loan $)$ & & & & & & $\begin{array}{c}-0.133 * * * \\
(0.045)\end{array}$ \\
\hline Share IRB & $\begin{array}{l}-0.012 \\
(0.021)\end{array}$ & $\begin{array}{c}0.086 * * \\
(0.039)\end{array}$ & $\begin{array}{l}-0.022 \\
(0.024)\end{array}$ & $\begin{array}{c}0.018 \\
(0.034)\end{array}$ & & \\
\hline $\mathrm{D}$ (IRB loan) & & & & & $\begin{array}{l}-0.013 \\
(0.011)\end{array}$ & $\begin{array}{l}0.066^{* *} \\
(0.027)\end{array}$ \\
\hline $\mathrm{D}$ (high exposure) & $\begin{array}{c}-0.143 * * * \\
(0.018)\end{array}$ & & $\begin{array}{c}-0.113 * * * \\
(0.017)\end{array}$ & & $\begin{array}{c}-0.181 * * * \\
(0.042)\end{array}$ & \\
\hline $\mathrm{D}$ (large loan) & & $\begin{array}{c}-0.111 * * * \\
(0.009)\end{array}$ & & $\begin{array}{c}-0.114 * * * \\
(0.008)\end{array}$ & & $\begin{array}{c}-0.150 * * * \\
(0.018)\end{array}$ \\
\hline Constant & $\begin{array}{l}0.818^{* * *} \\
(0.093)\end{array}$ & $\begin{array}{c}0.020 \\
(0.063)\end{array}$ & $\begin{array}{c}0.585 * * * \\
(0.060)\end{array}$ & $\begin{array}{c}0.070 \\
(0.045)\end{array}$ & $\begin{array}{c}1.142 * * * \\
(0.226)\end{array}$ & $\begin{array}{c}0.121 \\
(0.163)\end{array}$ \\
\hline Bank Controls & YES & YES & YES & YES & YES & YES \\
\hline Observations & 182,966 & 182,966 & 121,549 & 121,549 & 90,500 & 90,500 \\
\hline R-squared & 0.020 & 0.043 & 0.009 & 0.025 & 0.023 & 0.049 \\
\hline
\end{tabular}

These regressions examine whether the impact of the regulatory approach differs across loan characteristics. As before, our quarterly data are collapsed into single pre- and post-crisis time periods and the dependent variable is the change in $\log (\operatorname{loans})$ for a bank-firm relationship. We include all loans in columns 1 and 2 (Test 1), only SA loans in columns 3 and 4 (Test 2) and only loans from IRB banks in columns 5 and 6 (Test 3). We calculate a bank's exposure to a certain loan by dividing its amount by the bank's total assets prior to the crisis and separate our sample into those loans where the exposure of the bank is lower than median and those where it is higher than median. The resulting dummy variable is interacted with the share of IRB loans with the bank in columns 1 and 3 and with the IRB loan dummy in column 5. Alternatively, we generate a dummy that takes the value 1 for loans that are larger than the median loan in our sample and interact it with the respective IRB variables in columns 2, 4, and 6. Robust standard errors adjusted for clustering at the bank level are reported in parentheses. Note: * indicates statistical significance at the $10 \%$ level, ** at the $5 \%$ level and $* * *$ at the $1 \%$ level. 
Table 8: Firm cross-section

\begin{tabular}{|c|c|c|c|c|c|c|}
\hline \multicolumn{7}{|c|}{ Dependent variable: $\Delta \log ($ loans $)$} \\
\hline & \multicolumn{3}{|c|}{ Test 1} & \multicolumn{3}{|c|}{ Test 3} \\
\hline & (1) & (2) & (3) & (4) & (5) & $\begin{array}{c}\text { (6) } \\
\text { (6) }\end{array}$ \\
\hline Share IRB & $\begin{array}{c}-0.045^{* *} * \\
(0.023)\end{array}$ & $\begin{array}{c}-0.063 * * \\
(0.030)\end{array}$ & $\begin{array}{l}-0.022 \\
(0.026)\end{array}$ & & & \\
\hline $\mathrm{D}$ (IRB loan) & & & & $\begin{array}{c}-0.032 * * \\
(0.013)\end{array}$ & $\begin{array}{c}-0.043 * * \\
(0.020)\end{array}$ & $\begin{array}{l}-0.018 \\
(0.019)\end{array}$ \\
\hline Bank controls & YES & YES & YES & YES & YES & YES \\
\hline Firm FE & YES & YES & YES & YES & YES & YES \\
\hline Observations & 17,332 & 8,718 & 8,614 & 14,460 & 7,130 & 7,330 \\
\hline R-squared & 0.362 & 0.361 & 0.364 & 0.324 & 0.321 & 0.329 \\
\hline \multicolumn{7}{|c|}{ Panel B: Change in firm PD } \\
\hline & \multicolumn{3}{|c|}{ Test 1} & \multicolumn{3}{|c|}{ Test 3} \\
\hline & $\begin{array}{c}\text { (1) } \\
\text { All firms }\end{array}$ & $\begin{array}{c}\text { (2) } \\
\text { PD up }\end{array}$ & $\begin{array}{c}(3) \\
\text { PD down }\end{array}$ & $\begin{array}{c}\text { (4) } \\
\text { All firms }\end{array}$ & $\begin{array}{l}\text { (5) } \\
\text { PD up }\end{array}$ & $\begin{array}{c}\text { (6) } \\
\text { PD down }\end{array}$ \\
\hline Share IRB & $\begin{array}{c}-0.046 * * \\
(0.022)\end{array}$ & $\begin{array}{c}-0.062 * * * \\
(0.024)\end{array}$ & $\begin{array}{l}-0.031 \\
(0.028)\end{array}$ & & & \\
\hline D(IRB loan) & & & & $\begin{array}{c}-0.033^{* *} \\
(0.013)\end{array}$ & $\begin{array}{c}-0.041^{* * *} \\
(0.015)\end{array}$ & $\begin{array}{l}-0.028 \\
(0.018)\end{array}$ \\
\hline Bank controls & YES & YES & YES & YES & YES & YES \\
\hline Firm FE & YES & YES & YES & YES & YES & YES \\
\hline Observations & 16,154 & 8,018 & 8,136 & 13,445 & 6,646 & 6,799 \\
\hline R-squared & 0.369 & 0.389 & 0.380 & 0.330 & 0.348 & 0.343 \\
\hline
\end{tabular}

This table reports results for a matched sample of up to 17,332 loans to 4,906 firms for which we are able to obtain balance sheet information and that borrow from at least one SA bank and one IRB bank or at least two distinct IRB banks (Test 1) or that have at least one SA loan and one IRB loan (Test 3). As before, our quarterly data are collapsed into single pre- and post-crisis time periods and the dependent variable is the change in $\log$ (loans) for a bank-firm relationship. All regressions include firm fixed effects and the bank-level control variables from above. In Panel A, we separate our sample of firms into those with a lower than median pre-shock ROA and those with a higher than median pre-shock ROA and estimate Equation (1) (columns 1 to 3) and Equation (2) (Test 3) on each subsample. Similarly, Panel B divides our sample into firms for which the probability of default increased over the crisis and firms for which it decreased and runs separate regressions on each subsample. Robust standard errors adjusted for clustering at the bank level are reported in parentheses. Note: * indicates statistical significance at the $10 \%$ level, $* *$ at the $5 \%$ level and $* * *$ at the $1 \%$ level. 